\title{
AN EARLY PLEISTOCENE ANOMALOHALINE WATER OSTRACOD FAUNA FROM LAKE DEPOSITS OF THE HOMO ERECTUS-BEARING KOCABAŞ LOCALITY (SW TURKEY)
}

\author{
Lea Rausch $^{\mathrm{a}, \mathrm{b}_{*}}$ \& Marius Stoica ${ }^{\mathrm{a}}$
}

Received: 06 June 2019 / Accepted: 2 September 2019 / Published online: 6 September 2019

\begin{abstract}
The early Pleistocene travertines from the Denizli Basin in SW Anatolia, from which the only known Homo erectus finding from Turkey was recovered, are unconformably overlain by a $20 \mathrm{~m}$ thick succession of alkaline lake deposits that bear a rich ostracod fauna. The ostracod assemblage consists of a mixture of freshwater and mesohaline tolerant taxa. The following sixteen species have been identified: Candona neglecta, $C$. ex. gr. candida, Cypria sp., Darwinulina stevensovi, Lineocypris sp., Prinocypris zenkeri, Cyrpideis torosa, C. sp., Tyrrhencythere pontica, T. ex. gr. bailovi, T. sp. 1, T. sp. 2, Amnicythere pediformis, A. mutlituberculata, Loxoconchissa (Loxocaspia) aff. reticulata, L. (L.) aff. reticulata var. rugosa. The conditions inside the lake were interpreted from the encountered assemblage, suggesting a restricted anomalohaline shallow water environment with a salinity no greater than lower mesohaline. The age of the studied succession was previously constrained by cosmogenic nuclide concentration, palaeomagnetic measurements and large mammal biostratigraphy which suggest deposition occurred between $\sim 1.6$ and $1.1 \mathrm{Ma}$.
\end{abstract}

Keywords: Denizli Basin, Palaeoecology, Ostracods, Taxonomy, Homo erectus, Quaternary.

\section{INTRODUCTION}

The goals of palaeoanthropology reach far beyond the discovery of human fossils and extend to how environmental changes have shaped the human evolution (Kingston, 2007). The direction of evolutionary traits as the results of interaction between early hominids with their surroundings consequently demands a highly interdisciplinary approach. Ostracods represent one of the main groups of organisms living in aquatic habitats. In the marine realm they are not as abundant as other microfossils, especially foraminifera, however they play a key role in marginal marine and continental aquatic environments, providing the most ubiquitous and abundant calcareous microfossil (Lister, 1988). Their biological and palaeontological virtues (e.g. long fossil record, high abundances/diversity, adaptability to environmental changes, resistant eggs, etc.), render them as a valuable tool in biostratigraphy, palaeogeographic reconstruction and palaeoecology (Whatley, 1983a, b). Yet, ostracods are considered exotic, being utilized as palaeoecological indicators in palaeoanthropology related studies (Frenzel et al., 2006).

The Denizli Basin, accommodating the oldest Homo erectus fossil in Turkey, is located within one of the most active extensional tectonic areas in the world (Fig. 1a; Westaway, 1993). The basin is trending WNW-ESE and is approximately $50 \mathrm{~km}$ wide and $70 \mathrm{~km}$ long (Şimşek, 1984; Alçiçek et al., 2007). It is hosting basin-fill successions that are exhibiting a complex Miocene to Quaternary history and are reaching up to $1300 \mathrm{~m}$ in thickness, consisting of alluvial-fan, fluvial and lacustrine deposits (Şimşek, 1984; Alçiçek et al., 2007; 2015; Sun, 1990; Koçyiğit, 2005; Kaymakç1, 2006). Previous geological studies of the Denizli Basin concluded on a two-phase tectonic evolution of the basin: i) incipient/initial supradetachment basin developed during the early-middle Miocene (Lips et al., 2001; Sözbilir, 2005) and ii) subsequent high-angle faults cross-cut of previous structures driving the basin evolution and the present basin configuration development, since the Late Miocene. During the Quaternary diffuse geothermal activity triggered an extensive travertine formation that can be found predominantly along faults in the northern part of the basin (e.g., Altunel, 1994; Şimşek, 1984; Bozkurt, 2003; Alçiçek et al., 2013, 2016, 2018). These travertine deposits, especially around the town of Kocabaş (Figs. 1b, 2), have been quarried for commercial purpose for decades, yielding a variety of marcomammal findings, including the fragmentary Homo erectus skull that was discovered in 2002 (Kappelman et al., 2008; Vialet et al., 2014; 2018). The skull is considered the oldest Homo erectus fossil from the Anatolia region, presenting an intermediate morphological pattern between the Homo erectus findings from Dmanisi (Georgia) and Zhoukoudian Lowercave (China) at the crossroads of Europe and Asia (Kappelman et el., 2008; Vialet et al., 2012; Vialet et al., 2018; Lebatard et al., 2014).

Within the Faber quarry (Fig. 2), travertine and lake deposit exposures have been available since decades. The age of the succession has previously been constrained by cosmogenic nuclide concentration, palaeomagnetic measurements and large mammal-based biostratigraphy between $~ 1.6$ and 1.1 Ma (Lebatard et al., 2014; Boulbes et al., 2014). The early Pleistocene travertine unit that hosts the hominid fossil is covered by a succession of fluviolacustrine deposits (i.e. Upper Conglomerates Unit) that contains sedimentary and fossil evidence, providing the

\footnotetext{
${ }^{a}$ Faculty of Geology and Geophysics,University of Bucharest, Balcescu Bd. 1, 010041 Bucharest, Romania; phone: +49 17684879931,

*Corresponding author: leanrausch@gmail.com; marius.stoica@g.unibuc.ro

${ }^{\mathrm{b}}$ Department of Animal Ecology and Systematics, Justus Liebig University, Giessen, Germany
} 

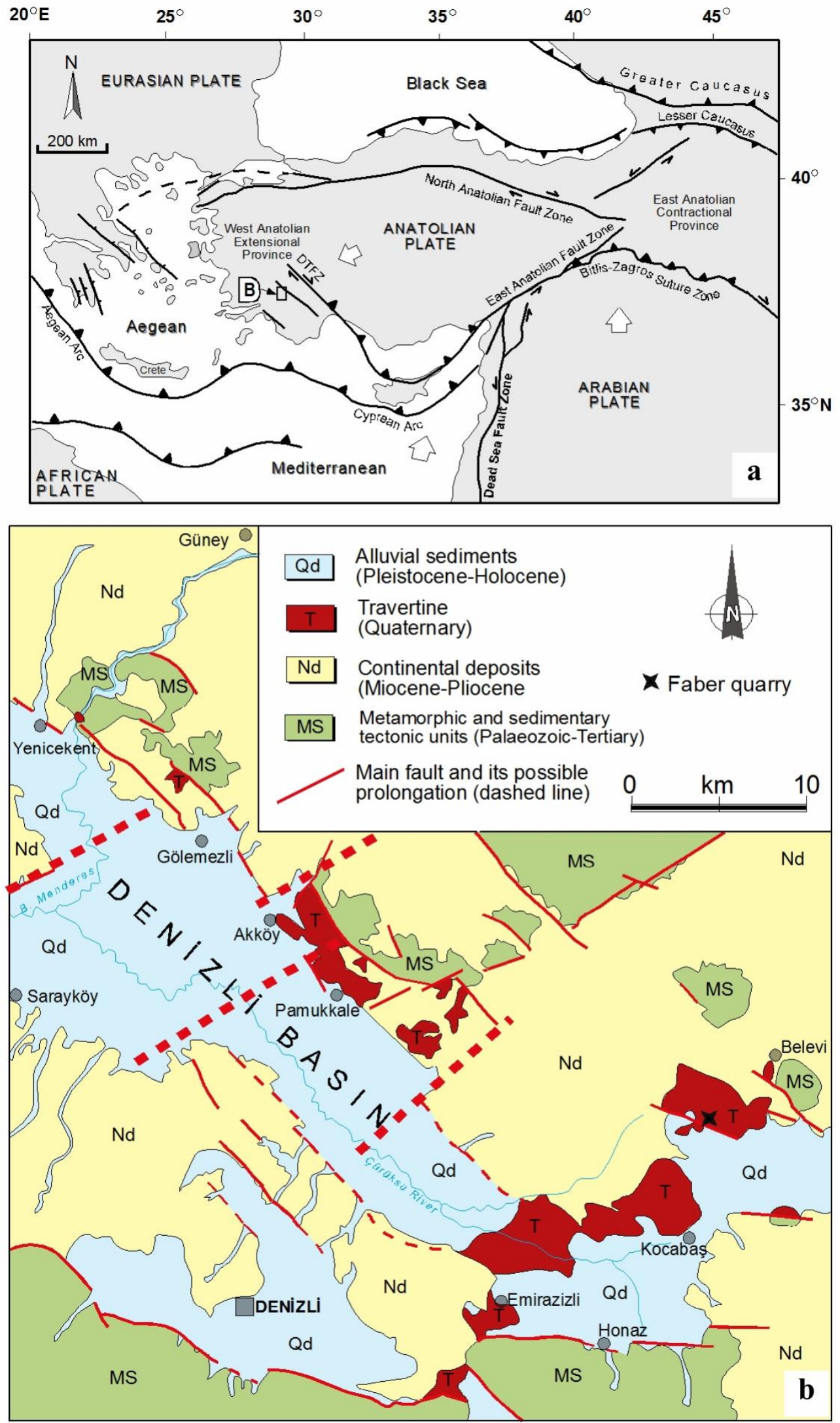

Fig. 1a Location of the Denizli Basin; b. Geological map of the Denizli Basin with indication of travertine units exposed (based on Sun, 1990). 


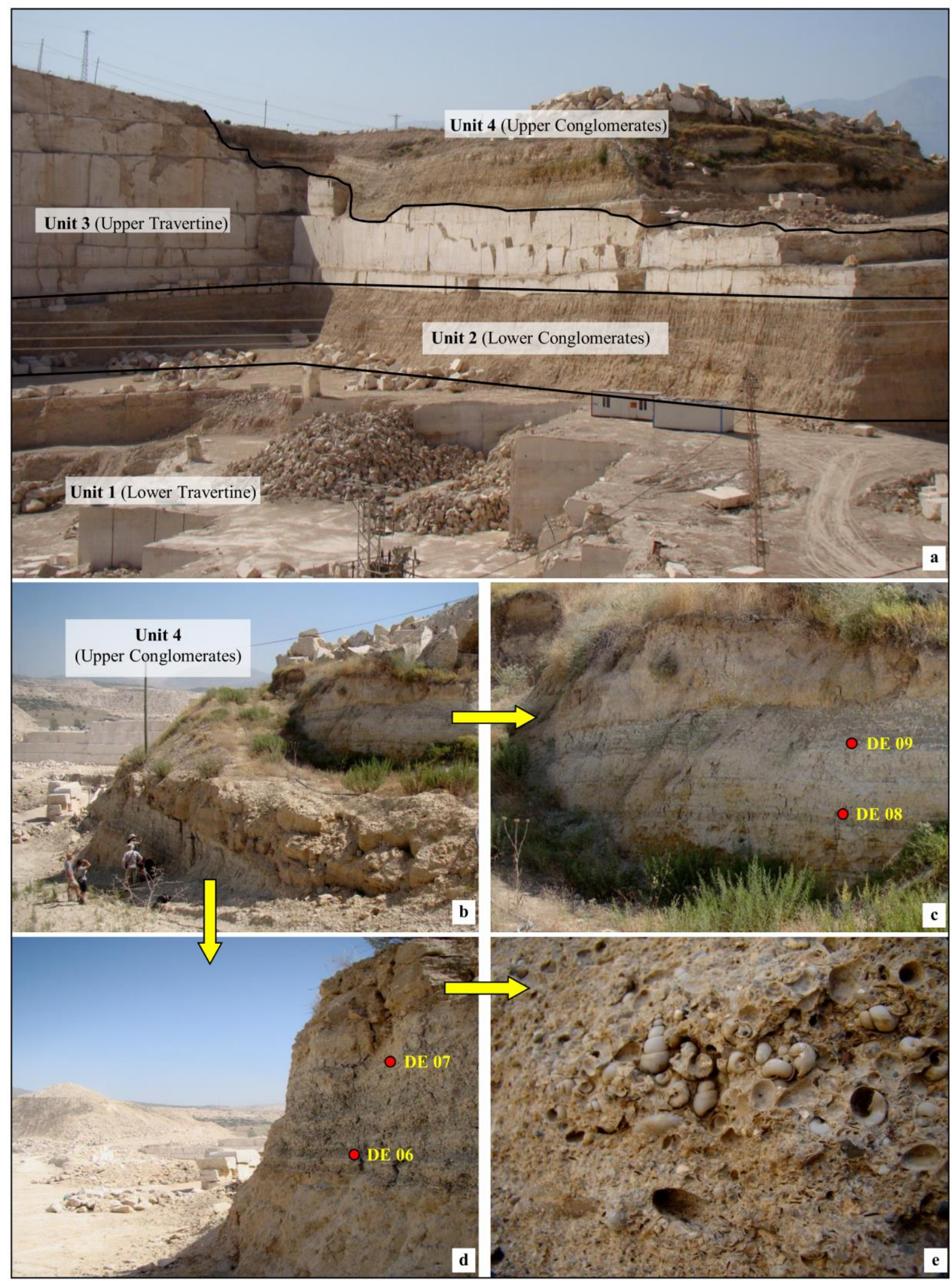

Fig. 2 a Southern corner of the Faber quarry with an overview of the section composed of four units; b-d Detailed pictures

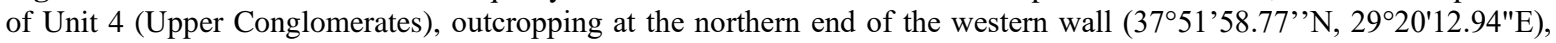
with position of micropalaeontological samples within clay intercalations; e Layer with recrystallized mollusc shells within the Upper Conglomerates; (DE 06- DE 09, micropalaeontological samples) (from Rausch et al., 2019). 
means to study the palaeoecological context that is the subject to the herein accomplished investigation. The ostracods studied in the present paper have previously supplied reliable palaeoenvironmental data towards a combined palaeontological and sedimentological study, approaching the Kocabaş travertine and fluvio-lacustrine succession (Rausch et al., 2019 accepted in Geobios). Here, we determined the species and provide a detailed discussion on their taxonomy. Based on the taxonomic outcomes we related species to specific environmental conditions with the goal of reconstructing the hydrological environment for Homo erectus during the early Pleistocene.

The results of this research may serve to improve both our understanding of the palaeoenvironment of early hominids in Anatolia as well as improve regional ostracod taxonomy.

\section{METHODS}

The stratigraphy of the succession was established from observations of layers exposed mostly vertical in the southern corner of the Faber quarry (Fig. 2). The approximately $95 \mathrm{~m}$ thick section is composed of four units (Figs.2, 3) first established in the geochronological study of Lebatard et al. (2014). It is important to point out that the terminology of the units follows the commercially used and not the correct lithological term. The units are defined as followed, from bottom to top: Unit 1(Lower Travertine), Unit 2 (Lower Conglomerates), Unit 3 (Upper Travertine) and Unit 4 (Upper Conglomerates). In this study we focus on the ostracod association from the uppermost unit of the succession (Upper Conglomerates).

The Upper Conglomerates Unit was sampled during April 2015 and consists of approximately $20 \mathrm{~m}$ of carbonate sands intercalated with stratified clays, silts and sands and cross stratified mixed carbonate-lithoclastic conglomerates containing a shelly fauna (Fig. 2b-e) (Rausch et al., 2019 accepted in Gebios). The sampled succession is stratigraphically located above Unit 3 (Upper Travertine) the Homo erectus fragmentary skull was found in and is exposed on the western side of the Killik hill (37 51'58.77' 'N, 29²0'12.94"E). In April 2018 another section, also encompassing the Upper Conglomerates, located on the eastern flank of the Killik hill (37'51'47.80"N, 29²0'16.07"E; Fig. 4) was sampled in order to test the lateral facies distribution. In addition to that, the Upper Conglomerates unit that was already sampled in April 2015 was re-sampled at similar levels. The lower part of the unit (Fig. 3), which progressively onlaps onto Unit 3, is composed of a sandy-silty conglomerate containing medium-sized pebbles, followed by an interval of fine laminated clay-and siltstones. The overlaying lithoclastic conglomerates hosts a rich and mostly recrystallized mollusc fauna (Fig. 2e). The succession continues with a finely laminated siltstone bed intercalated between sandstone deposits and terminates with a well-sorted conglomerate at the top.

A number of 15 ostracod samples derived from the fine grained intercalations were processed using standard micropalaeontological methods following procedures outlined in Stoica et al., 2013. To improve disaggregation, samples were boiled with sodium carbonate before being subsequently washed and sieved over a battery of three sieves $(500-125-63 \mu \mathrm{m})$. The dried residue was handpicked using a ZEISS - GSZ light microscope. For high resolution images the ZEISS MERLIN GEMINI 2 scanning electron microscope (SEM) of the Geological Institute of Romania (Microcosmos Laboratory) was used. The material is housed in the Faculty of Geology and Geophysics, Department of Geology, Laboratory of Palaeontology at Bucharest University (Romania).

The taxonomic concept is based on previously published work by Moore (1961), Van Morkhoven (1962) and Hartmann (1966). For the suprageneric classification we followed Meisch (2000) and Horne et al. (2002). For describing the taxonomy some of the most distinct and abundant elements of the assemblage encountered were considered.

\section{SYSTEMATIC PALAEONTOLOGY}

Phyllum Arthropoda Siebold \& Stannius, 1845

Class Ostracoda Latreille, 1806

Subclass Podocopa Latreille, 1802

Order Podocopida Sars, 1866

Suborder Cypridocopina Jones, 1901

Superfamily Cypridoidea Baird, 1845

Family Candonidae Kaufmann, 1900

Subfamily Candoninae Kaufmann. 1900

Genus Candona Baird, 1845

\section{Candona neglecta Sars 1887}

Fig. 5a-1; Fig. 6a-d

\begin{tabular}{|c|c|c|}
\hline 1887 & $\begin{array}{l}\text { Candona ne- } \\
\text { glecta } \mathrm{n} . \mathrm{sp} \text {. }\end{array}$ & $\begin{array}{l}\text { - Sars, pp. 279-288, pl. } 15 \text {, } \\
\text { figs. } 5-7, \text { pl. 19, figs. } 1-21 .\end{array}$ \\
\hline 1969 & $\begin{array}{l}\text { Candona ne- } \\
\text { glecta Sars par- } \\
\text { tim }\end{array}$ & $\begin{array}{l}\text { - Diebel \& Pietrzeniuk, } \\
\text { p.473, pl. } 7 \text {, figs. 6-8. }\end{array}$ \\
\hline 1980 & $\begin{array}{l}\text { Candona ne- } \\
\text { glecta Sars }\end{array}$ & $\begin{array}{l}\text { - Freels, p. 94, pl. 16, figs. } \\
12-19 .\end{array}$ \\
\hline 2000 & $\begin{array}{l}\text { Candona ne- } \\
\text { glecta Sars }\end{array}$ & $\begin{array}{l}\text { - Meisch, p. 77, figs. 26A- } \\
\text { C, 27A-B. }\end{array}$ \\
\hline 2001 & $\begin{array}{l}\text { Candona ne- } \\
\text { glecta Sars }\end{array}$ & $\begin{array}{l}\text { - Tunoğlu \& Ünal, p. } 176 \text {, } \\
\text { pl. 3, fig. } 1 .\end{array}$ \\
\hline 2005 & $\begin{array}{l}\text { Candona ne- } \\
\text { glecta Sars }\end{array}$ & $\begin{array}{l}\text { - Pipík \& Bodergat, p. 290, } \\
\text { pl. 2, figs. } 1-5 .\end{array}$ \\
\hline 2005 & $\begin{array}{l}\text { Candona ne- } \\
\text { glecta Sars }\end{array}$ & $\begin{array}{l}\text { - Matzke-Karasz \& Witt, p. } \\
\text { 120, pl. 1, figs. 6-7. }\end{array}$ \\
\hline 2008 & $\begin{array}{l}\text { Candona ne- } \\
\text { glecta Sars }\end{array}$ & - Fuhrmann, pl.2, figs. $2 \mathrm{a}-\mathrm{d}$ \\
\hline 012 & $\begin{array}{l}\text { Candona ne- } \\
\text { glecta } \text { Sars }\end{array}$ & $\begin{array}{l}\text { - Fuhrmann, p. } 32 \text {, pl. 10, } \\
\text { figs. 1a-f, 2a-d. }\end{array}$ \\
\hline
\end{tabular}

Description. The highly variable but usually elongated carapace shows an almost straight dorsal margin with a sloping to the anterior end. The ventral margin is concave. Form the dorsal view, the anterior end is slightly pointed rather than the posterior. The left valve (LV) overlaps the right valve (RV) at both ends. Similar to Candona angulata, this species shows a fine reticulate pattern in the posterior part, on the otherwise smooth valve. A number of close-set and curved anterior 


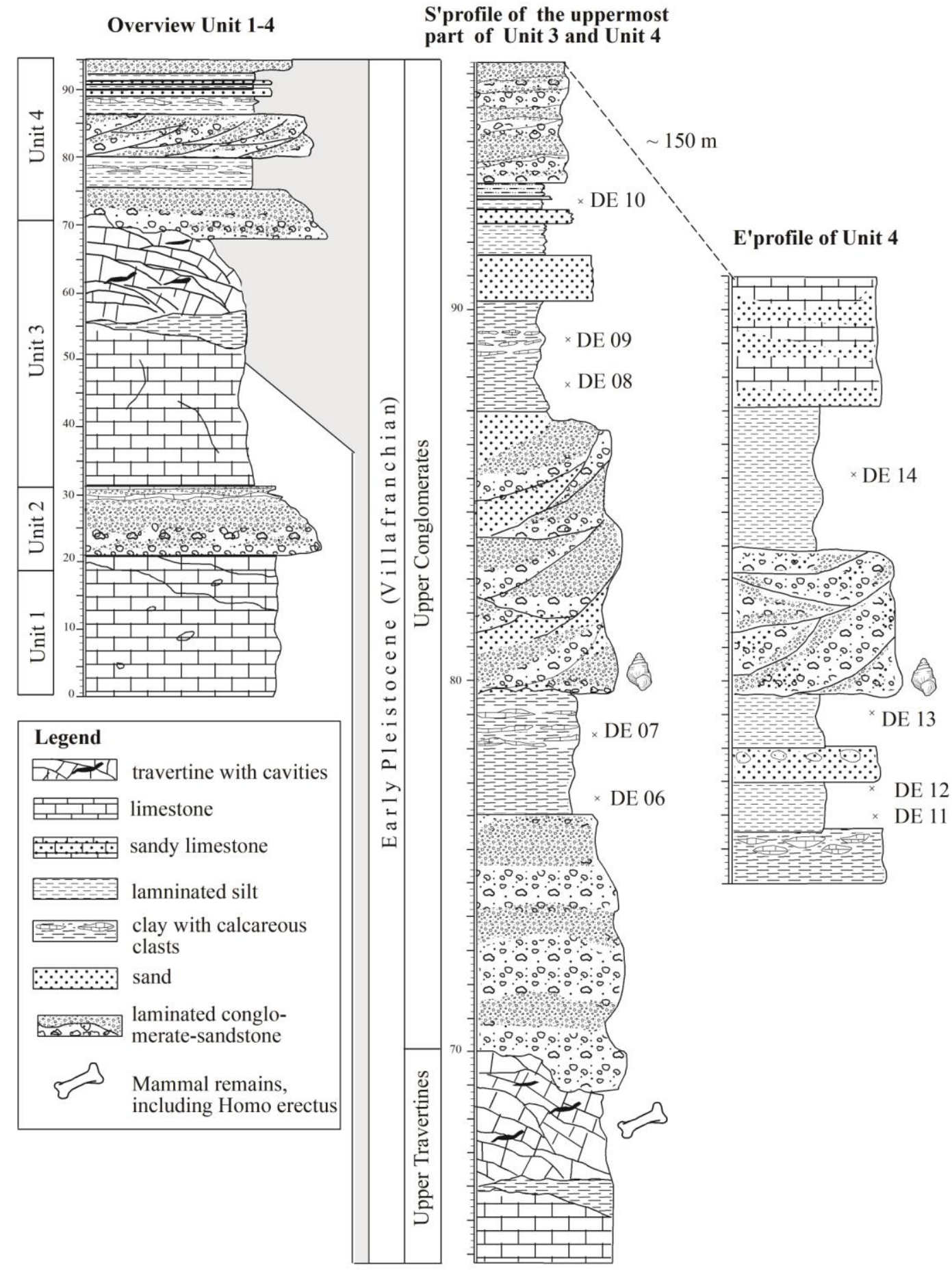

Fig. 3 Synthetic overview logs with main lithological characteristics and sampled intervals. Units from bottom to top: Unit 1, Lower Travertine, Unit 2, Lower Conglomerates, Unit 3, Upper Travertine and Unit 4, Upper Conglomerates. (DE 06- DE 14, micropalaeontological samples) (modified from Rausch et al., 2019).

marginal pore canals are present. The muscle scar forms a row of three scars with a larger elongated scar above. Sexual dimorphism is occurring. The male carapace is longer and the ventral concavity is more pronounced. Whenever valves are transparent, clear imprints of the male sexual organ can be noticed on the outer distal subdivided lobe. Dimension: Male: $\mathrm{L}=1.2-1.5 \mathrm{~mm} ; \mathrm{H}=$ 0.6-0.8 mm; Female: $\mathrm{L}=1.1-1.2 \mathrm{~mm} ; \mathrm{H}=0.6-0.7 \mathrm{~mm}$. Remarks. Different juvenile stages of $C$. neglelcta can be found in large numbers in freshwater sediments and usually been described and summarised under the name
"Candoniella" (Dan Danielopol personal communication).

Ecology. Candona neglecta occurs in a wide range of aquatic habitats and prefers slightly cold water but can tolerate temporary increase in temperature beyond $20{ }^{\circ} \mathrm{C}$. It has been reported from coastal-and inland waters with a salinity range of $0.5-16 \%$ (Meisch, 2000). In lakes it has been observed from the shallow littoral zone down to depths of $311 \mathrm{~m}$ (Lago Maggiore, Italy; Meisch, 2000). Together with Cyprideis. ex. gr. torosa and Ilyocypris gibba (Ramdohr) it has been described from freshwater 


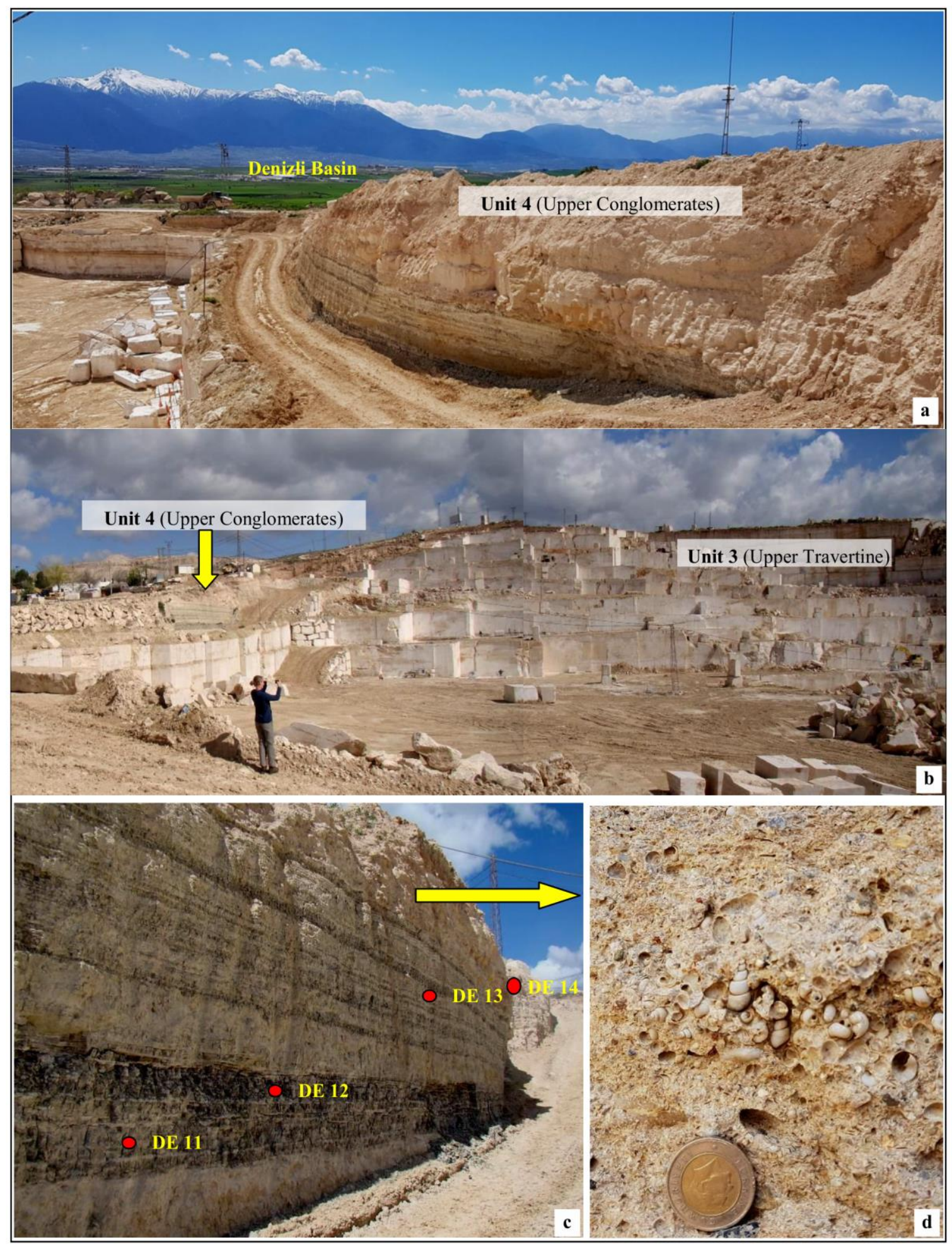

Fig. 4 a,b Overview of exposed units on the Eastern side of the Killik hill; c,d Detailed pictures of the clayey and mollusc bearing interval of the Upper Conglomerates (3751'47.80"N, $\left.29^{\circ} 20^{\prime} 16.07^{\prime \prime E}\right)$. 


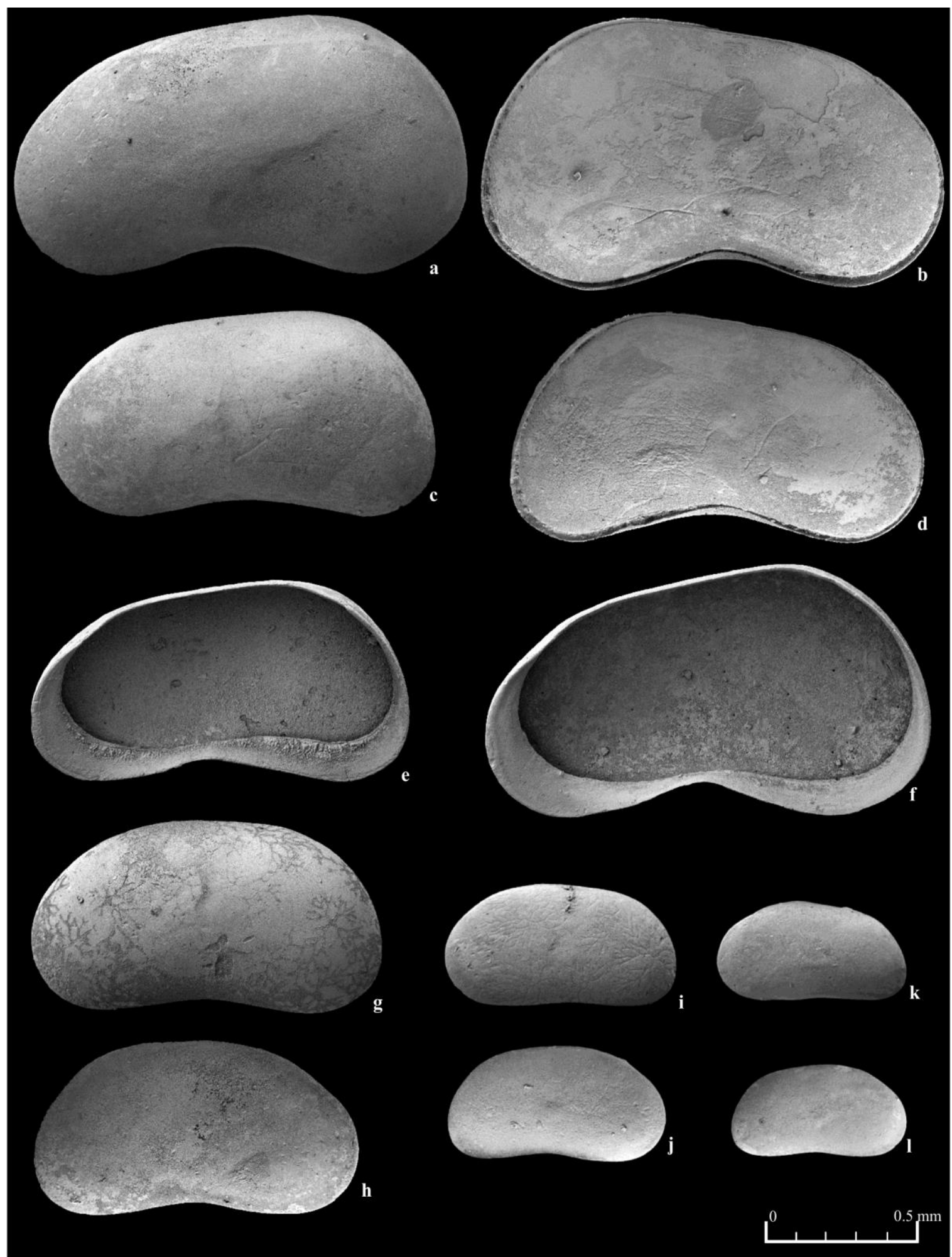

Fig. 5a-l Candona neglecta Sars; a. LV, external view, ô; b carapace, lateral view from RV, ô; c. LV, external view, $q$; d carapace, view from RV, $q$; e RV, internal view, + ; f RV, internal view, $\delta^{\lambda} ; \mathbf{g} \mathrm{LV}$, external view, A1 juvenile; h RV, external view, A1 juvenile; i LV, external view, A2 juvenile; j RV, external view, A2 juvenile; $\mathbf{k}$ LV, external view, A3 juvenile; $\mathbf{l}$ RV, external view, A3 juvenile (all specimens from sample DE06, Faber Quarry, Kocabaş, Denizli). 
assemblages from the Romanian stage of the Slănicul de Buzău section in the Dacian Basin (Van Baak et al., 2015).

Candona ex gr. candida (O. F. Müller, 1776)

Fig. 6e-j

\begin{tabular}{|c|c|c|}
\hline 1776 & Cypris candida & $\begin{array}{l}\text { O. F. Müller, p. 199, No. } \\
2385\end{array}$ \\
\hline 1956 & $\begin{array}{l}\text { Candona ex. gr. } \\
\text { candida (O. F. } \\
\text { Müller) }\end{array}$ & $\begin{array}{l}\text {-Suzin, p. 30, pl. XIV, } \\
\text { fig. } 4\end{array}$ \\
\hline 1961 & $\begin{array}{l}\text { Candona ex. gr. } \\
\text { candida (O. F. } \\
\text { Müller) }\end{array}$ & $\begin{array}{l}\text { Agalarova et al., p. } 54 \text {, } \\
\text { pl. } 27 \text {, figs. } 1,2 \text { a, b. }\end{array}$ \\
\hline 1963 & $\begin{array}{l}\text { Candona candida } \\
\text { O. Müller }\end{array}$ & $\begin{array}{l}\text { Mandelstam \& } \\
\text { Schneider, p. } 150 \text {, pl. } 23 \text {, } \\
\text { fig. } 3 \text {. }\end{array}$ \\
\hline 1986 & $\begin{array}{l}\text { Candona ex. gr. } \\
\text { candida (O. F. }\end{array}$ & $\begin{array}{l}\text { - Yassini, p. 88, pl 4, } \\
\text { figs. } 1,2 \text {. }\end{array}$ \\
\hline 2000 & $\begin{array}{l}\text { Candona candida } \\
\text { (O. F. Müller) }\end{array}$ & $\begin{array}{l}\text { Meisch, p. 65, Figs. } 20 \\
\text { A-C; } 21 \text { A, B; } 22 \text { A, B }\end{array}$ \\
\hline 2012 & $\begin{array}{l}\text { Candona candida } \\
\text { (O. F. Müller) }\end{array}$ & $\begin{array}{l}\text { Fuhrmann, p. } 26, \text { pl. } 7 \text {, } \\
\text { figs. 1a-d, } 2 \text { a-f. }\end{array}$ \\
\hline
\end{tabular}

Description. The carapace commonly shows a wide variety of forms but in general is of elongated shape with the greatest height slightly behind mid length. The dorsal margin is slightly convex and slopes smoothly onto the broadly rounded anterior end whereas towards the posterior it is convex and steeply sloping. The lower part of the LV appears slightly pointed and continues in a round fashion onto the ventral margin distinctively concave in the median area and passes smoothly onto the narrowly rounded posterior-ventral end. The LV overlaps the RV at both ends. A number of close-set and curved anterior marginal pore canals are present in the widely pronounced marginal area. Sexual dimorphism is occurring. The male carapace appears to be slightly longer and the ventral concavity is more pronounced. Dimension: $\mathrm{L}=$ 1,02-1, $18 \mathrm{~mm} ; \mathrm{H}=0,52$ - 0,60 mm.

Ecology. C. candida is found in an exceptionally wide range of aquatic habitats, ranging from littoral to profundal zones of lakes (Meisch, 2000). It further has been observed in ponds and rivers and some juveniles prove to be resistant against desiccation, and from slightly salty (lower mesohaline) inland-and coastal waters. This species has been described in freshwater sediments from the Getian in the western region of the Dacian basin (Olteanu, 1995), the Apsheronian and Akciagilian level from the Circum-Causcasian area and Central Asia (Suzin, 1956; Agalarova et al., 1961; Yassini, 1986).

Subfamily Cyclocypridinae Kaufmann, 1900

Genus Cypria Zenker, 1854

\section{Cypria sp.}

Fig. 7a-f

Description. The thin-walled carapace is distinctly arched to triangular in lateral view and subovate in dorsal view. The greatest height is located slightly in front of the midlength. The ventral margin runs straight but shows a small depression about mid-length more visible from the interval view. The LV overlaps the RV. Both ends are almost symmetrically rounded with the anterior showing a slightly higher curvature. The dorsal margin is convex and notably pointed in the middle part. The surface of the valve is smooth. The inner lamella is moderately pronounced, with the anterior vestibulum being slightly wider than the posterior one. The hinge is adont and the dorsal margin of the smaller RV fits into a shallow groove in the LV. The central muscle scar forms a group of four larger scars and another two smaller scars that are located slightly below. Dimension: $1=0,52-0,55 \mathrm{~mm}, \mathrm{~h}=0,37-$ $0,40 \mathrm{~mm}$,

Remarks. Our species differs from Cypria oftalmica (Jurine) being more triangular in shape from the lateral view and showing a clearly symmetrical and pointed convex dorsal margin.

Ecology. Cypria is one of the most common fresh water genera (Van Morkoven, 1962) living in a wide range of aquatic habitats like ponds, pools and ditches rich in plants. Only few species of the genus Cypria are described to prefer oligo-to mesohaline water conditions (Keyser, 1977).

Subfamily Eucandonidae Swain, 1961

Genus Lineocypris Zalanyi, 1929

\section{Lineocypris sp.}

Fig. 8a-i

Description. The carapace is elongated, rectangular to trapezoidal in lateral view. The LV is slightly larger than the RV. The height of the carapace in general seems less than half the length. The anterior-and the posterior end are rounded in the lower part and slanted in the upper. The latter is more sharply slanted, prolonged and compressed. The dorsal margin is short and runs straight, parallel to the ventral margin that is slightly concave in the median area. The valves surface appears smooth. The inner lamella is moderately well developed in the both the anterior and posterior margin. The hinge is adont and the dorsal margin of the smaller $\mathrm{RV}$ fits into a shallow groove in the LV. Dimension: $1=1,15-1,30 \mathrm{~mm}, \mathrm{~h}=$ $0,61-0,73 \mathrm{~mm}$.

Ecology. The genus has been described from limnic to mesohaline waters (Morkhoven 1962; Sokač, 1972).

Subfamily Eucypridinae Bronshtein, 1947

Genus Prionocypris Brady \& Norman, 1896 


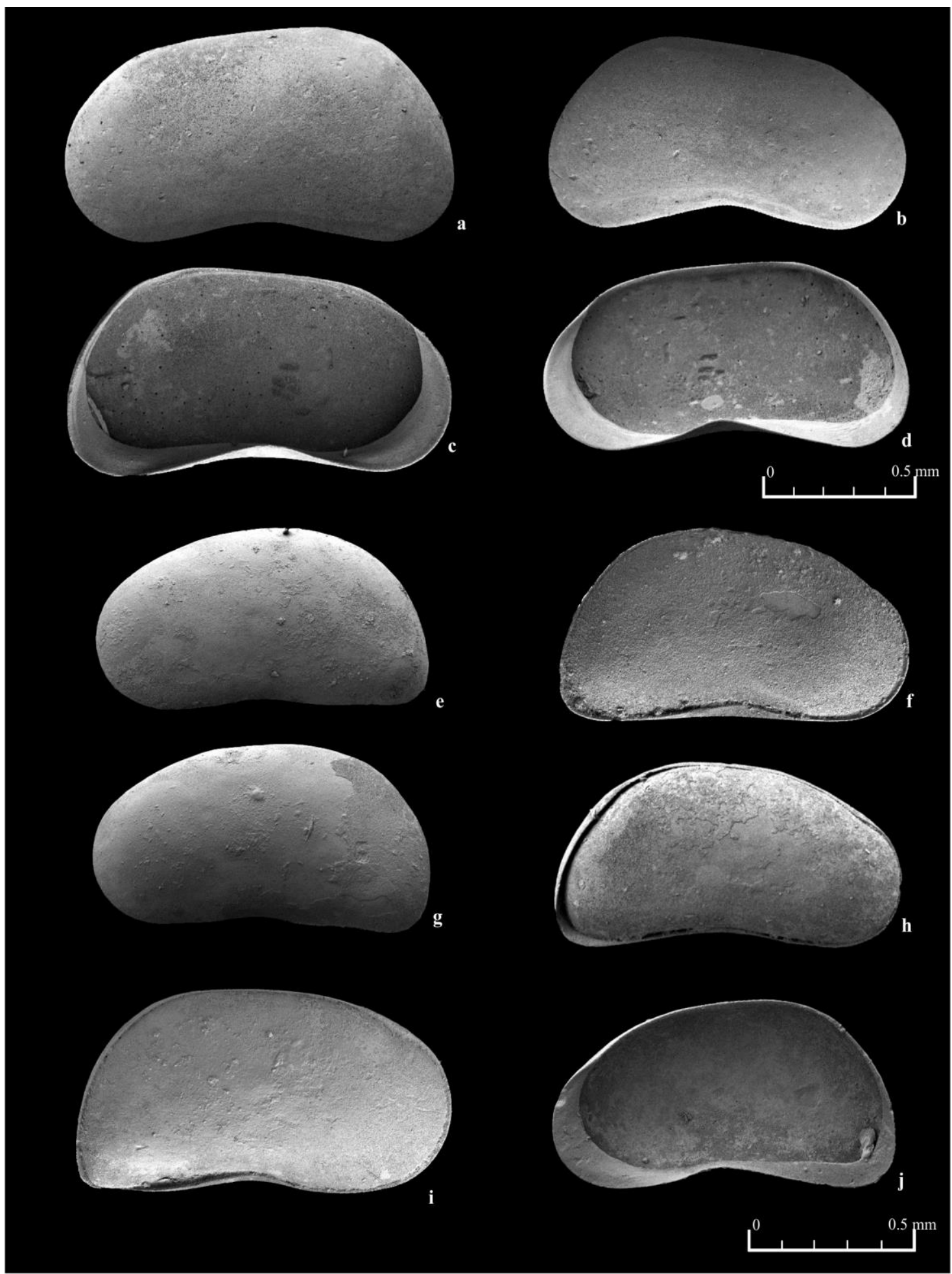

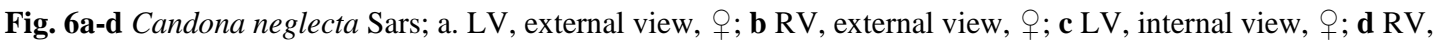
internal view,, ; e-j Candona ex. gr. candida (O. F. Müller); e, g LV, external view; f-i Carapace, lateral view from RV; j RV, internal view (all specimens from sample DE06, Faber Quarry, Kocabaş, Denizli). 


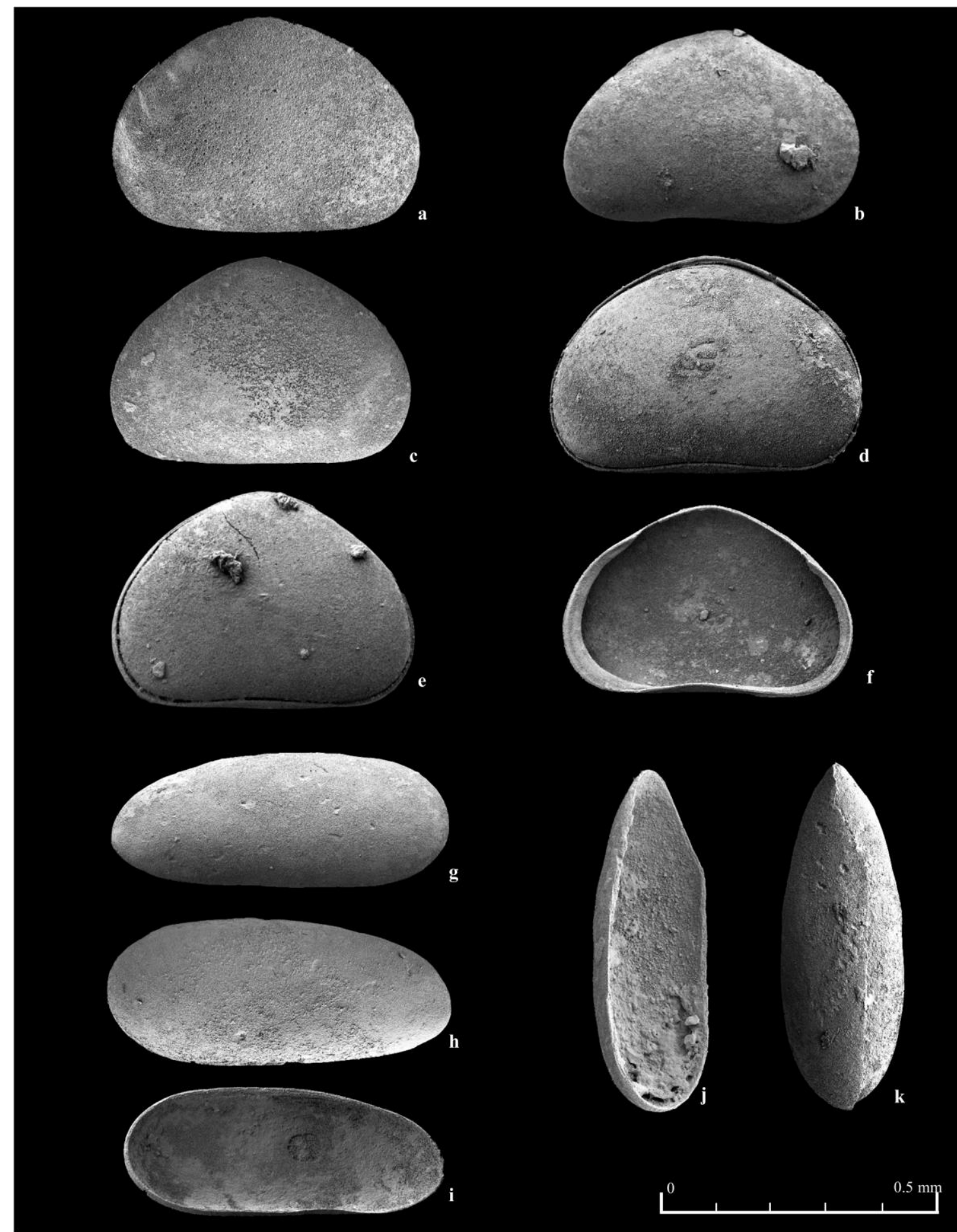

Fig. 7a-f Cypria sp.; a, c LV, external view; b. RV, external view; d, e Carapace, lateral view from RV; $\mathbf{f}$ RV, internal view; g-k Darwinula stevensoni (Brady \& Robertson); g LV, external view; h RV, external view; i, $\mathbf{j} L V$, internal view; k Carapace, ventral view (a-f, sample DE09; g-k, sample DE07; Faber Quarry, Kocabaş, Denizli). 


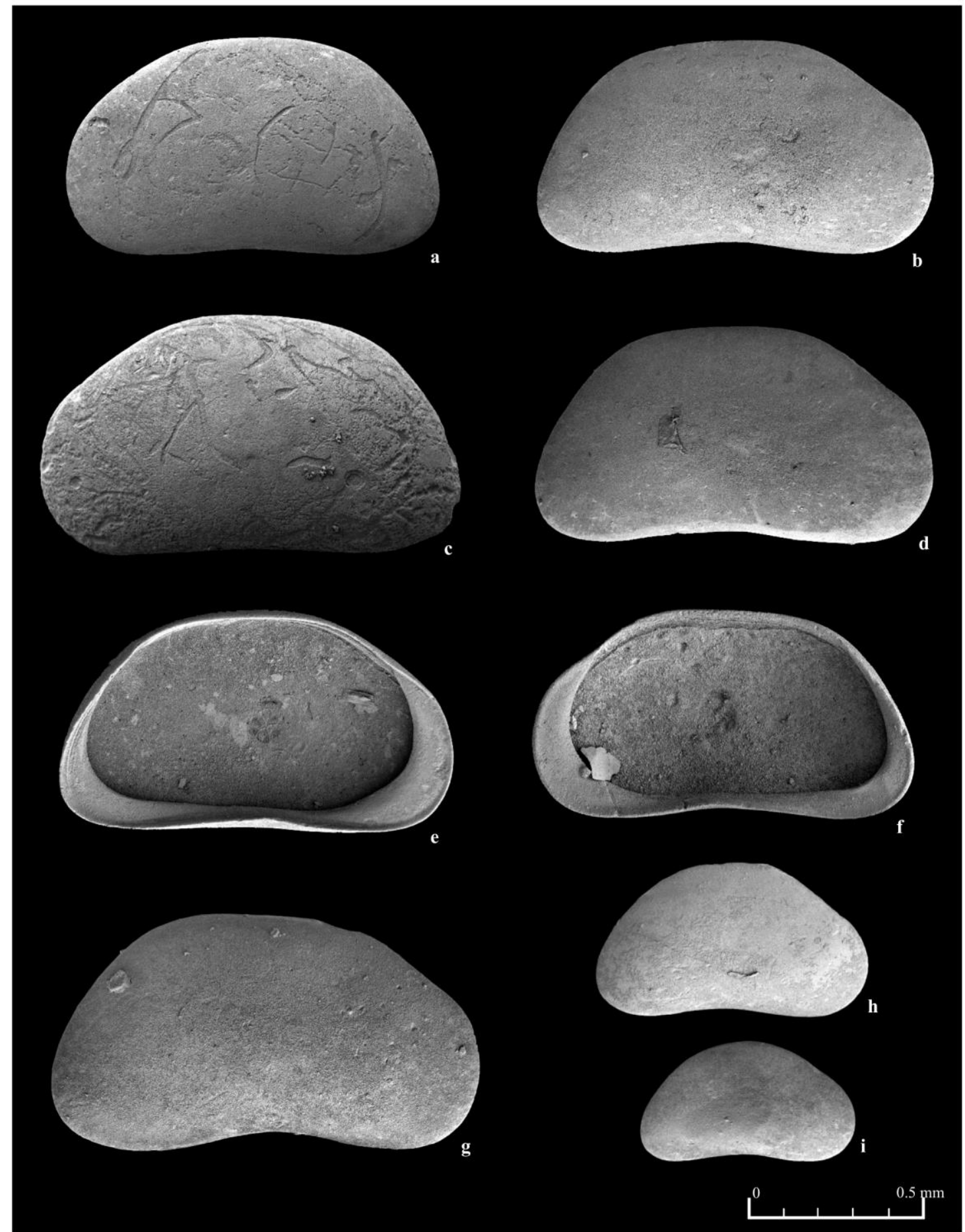

Fig. 8a-i Lineocypris sp.; a, c LV, external view; b, d, g RV, external view; e LV, internal view; f RV, internal view; h RV, external view, A1 juvenile; i RV, external view, A2 juvenile (all specimens from sample DE06, Faber Quarry, Kocabaş, Denizli). 
Prionocypris zenkeri (Chyzer, 1858)

Fig. 9a-m

1858

Cypris zenkeri - Chyzer, p. 514. n.sp.

1975

$\begin{array}{ll}\text { Prinocypris } & \text { - Diebel \& } \\ \text { zenkeri (Chyzer, } & \text { Wolfschläger, p. 111, pl. } \\ 1858) & \text { 18a-b. }\end{array}$

1984 Prinocypris - Diebel \& Pietrzeniuk, zenkeri (Chyzer, p. 306, pl. 7, fig. 7-8. 1858)

2000 Prinocypris - Meisch, p. 299, fig. zenkeri (Chyz- 126A-C. er\& Toth, 1858)

2012 Prinocypris zenkeri (Chyzer\& Toth, 1858)

- Fuhrmann, p. 200, pl. 94, figs. 2a-f.-

Description. The carapace is subovate to elongate in lateral view and has its greatest width slightly in front of the mid-length. Both, the anterior-and the posterior end, are end broadly rounded. The ventral margin is almost straight, but shows a slight depression mid-length. The dorsal margin is slightly arched shaped and steeply sloping down the anterior end as well as constantly inclining towards the posterior. The outer anterior margin of both valves (LV slightly longer than RV) posses 5-10 wartlike elevations (porenwarzen). The postero-ventral margin of both valves shows more than 10 fine spines, visible on well preserved specimens only. The fused zone and inner lamella are pronounced narrow in the posterior and moderate in the anterior end. The valves surface of the adults is covered by fine dense pits and polygonal fine reticulation on juveniles. Dimension: $1=1,30-1,45 \mathrm{~mm}, \mathrm{~h}$ $=0,70-0,75 \mathrm{~mm}$.

Ecology. The species is described from low energy streams that are rich in vegetation and less common in deeper and stagnant water bodies. It has also been found in ponds with cold water influx, living on calcareous substrates (Meisch, 2000; Fuhrmann, 2012). The fossil record of the species ranges from the Lower Pleistocene to Recent (Meisch, 2000).

Superfamily Darwinulacea Brad \& Norman, 1889

Family Darwinulidae Brady \& Norman, 1889

Genus Darwinula Brady \& Robertson, 1872

Darwinula stevensovi (Brady \& Robertson, 1870)

$$
\text { Fig. } 7 g-k
$$

1870 Policheles steven- - Brady \& Robertson, soni nov. sp. $\quad$ p. 25 , pl. 7 , figs. $1-7$, pl. 10, figs. 4-14.

1962 Darwinula ste- - Morkhoven, p. 29vensoni (Brady \& 31, figs. 35-38. Robertson)

1995 Darwinula ste- - Olteanu, pl.VIII; fig. vensoni (Brady \& 10.

Robertson)

2000 Darwinula ste- vensoni (Brady \& 16 A-E.

Robertson)

2012 Darwinula ste- - Fuhrmmann, p. 14, vensoni (Brady \& pl. 1, figs. 1 a-f.

Robertson)

2015 Darwinula stevensoni (Brady \&

Van Baak, fig. 7, 16Robertson)

Description. The carapace is elongated and subcylindrical in shape. From the side view both edges are rounded, whereas the RV overlaps the LV. The dorsal margin is slightly arched, whereas the ventral margin possesses a very slight concavity. The transition onto the anterior-and posterior end is smooth. The posterior is somewhat sharply rounded, unlike the anterior that appears more bluntly-rounded. The ornamentation is smooth and the carapace in general appears to be very thin and fragile. The muscle scar is typical for the genus, arranged in form of a rosette and the hinge is adont. Dimension: $1=0,59-0,64 \mathrm{~mm}, \mathrm{~h}=0,24-0,28 \mathrm{~mm}, \mathrm{~b}=$ $0,22 \mathrm{~mm}$

Ecology. The cosmopolitan Darwinulina stevensoni lives mostly in freshwater environments and has been described from recent oligohaline waters of SW Florida. Less common are occurrences in mesohaline environments with salinities up to $15 \mathrm{~g} / \mathrm{l}$ (Van Morkhoven, 1962; Keyser, 1977; Martens et al., 1997). Living representatives are usually to be found in littoral environments, for example along the Paraná river in southern Brazil (Higuti et al., 2009). The species is also inhabiting ponds, lakes and low energy streams. In the fossil record it has been described from Late Holocene sediments of the Black Sea (Briceag et al., 2012).

Superfamily Cytheracea Baird, 1850

Family Cytherideidae Sars, 1925

Genus Cyprideis Jones, 1857

Cyprideis torosa (Jones, 1850)

Fig.10a-k; Fig.11a-d

1850 Candona torosa - Jones, 2, 6: 27; pl. 3: 6a-e.

1925 Cyprideis litto- - Sars, p. 9: 155; pls. 71, ralis nov. comb. 72:1.

1995 Cyprideis torosa - Tunoğlu et al., pl. 1, fig. Jones 1-5.

1996 Cyprideis torosa - Boomer et al., p.83, fig. 4, Jones J-N.

2000 Cyprideis torosa - Meisch, p. 459, fig. 188Jones 189.

2005 Cyprideis torosa - Matzke-Karazs \& Witt, p. Jones 128, pl. 3, fig. 8-11.

2012 Cyprideis torosaf. - Fuhrmann, p. 294, pl. torosa (Jones) 141, figs. $1 \mathrm{a}-\mathrm{d}, 2,3 \mathrm{a}-\mathrm{d}, 4$.

2013 Cyprideis ex. gr. - Stoica et al., p. 140, pl. 2, torosa (Jones) fig. 2-3.

Description. The carapace has a subovate shape in lateral view and a gently arched dorsal margin. Posterior and 


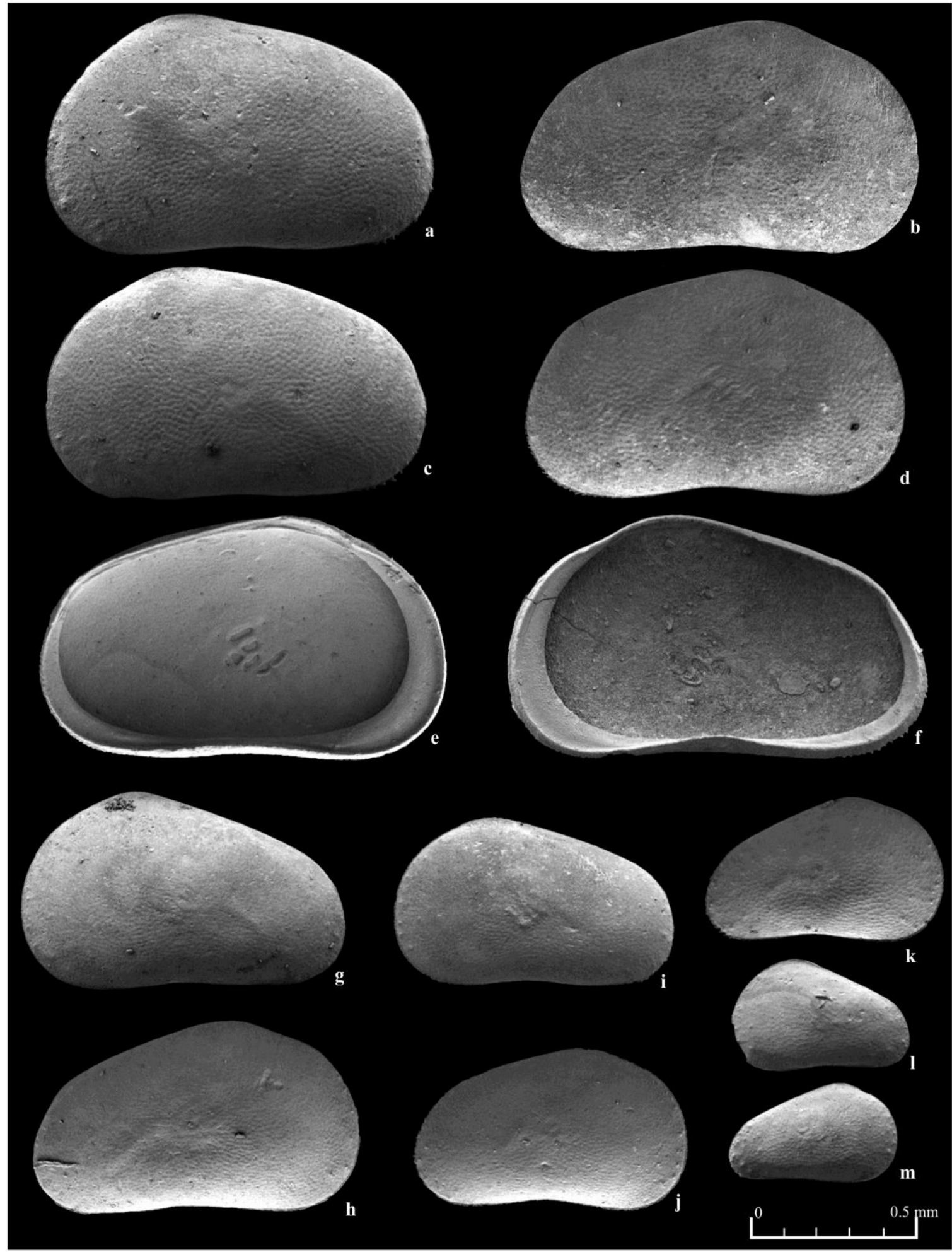

Fig. 9a-m Prionocypris zenkeri (Chyzer \& Toth); a, c LV, external view; b, d RV, external view; e LV, internal view; $\mathbf{f}$ $\mathrm{RV}$, internal view; $\mathbf{g} \mathrm{LV}$, external view, A1 juvenile; $\mathbf{h} \mathrm{RV}$, external view, A1 juvenile; i LV, external view, A2 juvenile; j RV, external view, A2 juvenile; $\mathbf{k}$ RV, external view, A3 juvenile; I LV, external view, A4 juvenile; m RV, external view, A4 juvenile (all specimens from sample DE11, Faber Quarry, Kocabaş, Denizli). 


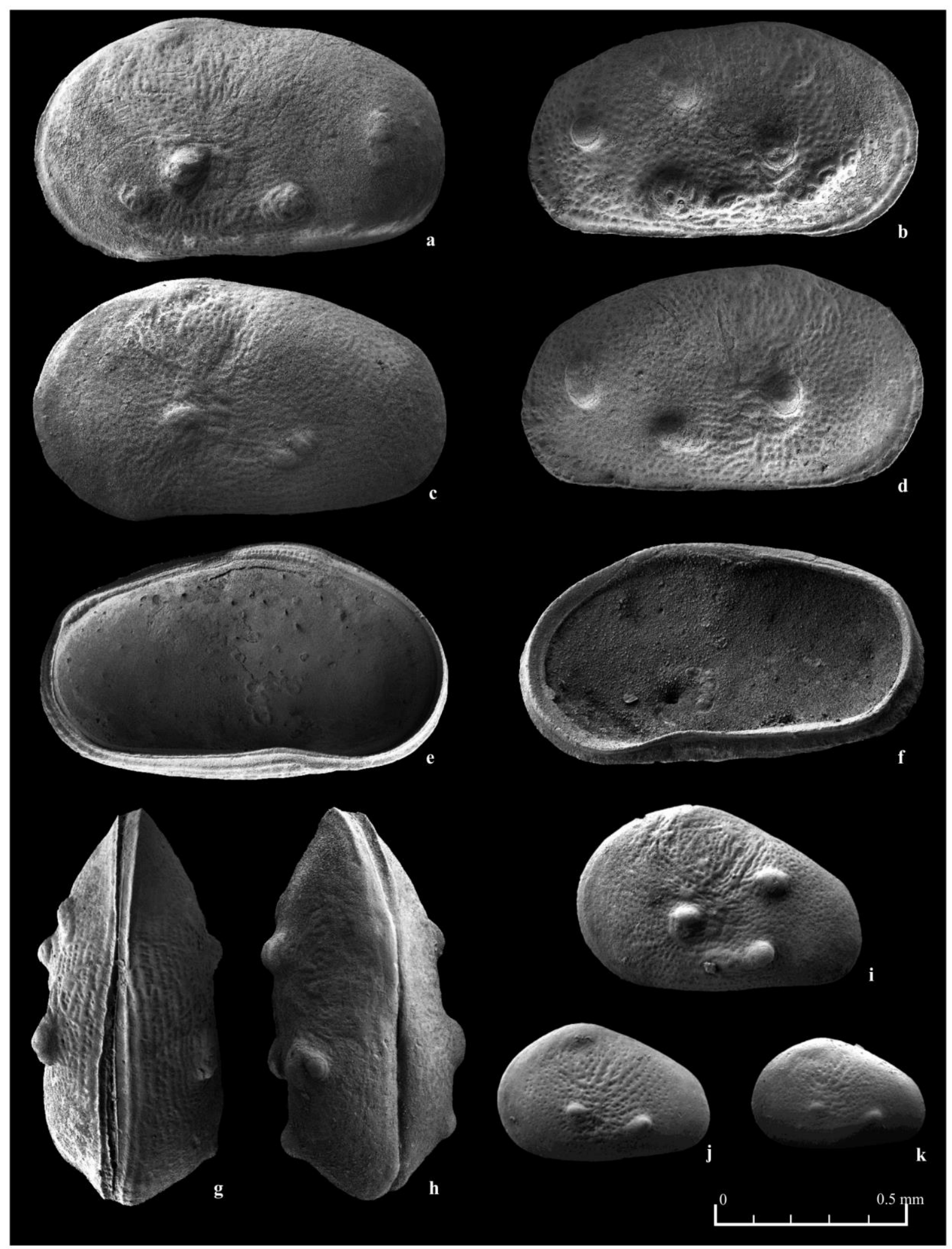

Fig. 10a-k Cyprideis torosa (Jones); a, c LV, external view,, ; b, d RV, external view,, ; e LV, internal view,, ; f RV, internal view, + ; g Carapace, ventral view, + ; h Carapace, dorsal view, + ; i LV, external view, A1 juvenile; j LV, external view, A2 juvenile; k LV, external view, A3 juvenile (all specimens from sample DE06, Faber Quarry, Kocabaş, Denizli). 
anterior margins are rounded. The greatest width of the carapace is slightly behind mid-length. The valves surface varies from having a fine reticulation to pitted ornamentation and can possess up to 7 phenotypic tubercles (nodes). Phenotypic tubercles are missing in the "unnodded" specimens illustrated in Fig. 11 (1-4), but the general aspects of the fine ornamentation remain. Sexual dimorphism is occurring and female specimen appear higher and more rounded in the posterior area whereas the male carapace is narrower and much more pointed towards the posterior end. Dimension: Female: $1=1,06$ $1,17 \mathrm{~mm}, \mathrm{~h}=0,57-0,63 \mathrm{~mm}, \mathrm{~b}=0,50-0,55 \mathrm{~mm}$; Male: 1 $=1,10-1,12 \mathrm{~mm}, \mathrm{~h}=0,57-0,60 \mathrm{~mm}$.

Ecology. C. torosa is geographically widespread occurring and found in a wide range of salinities from almost freshwater to fully marine conditions. It also has been reported from hypersaline habitats and can be found in coastal ponds, lakes, lagoons or other marginal marine environments but has never been reported from deep marine habitats (Meisch, 2000). It appears down to depth of $30 \mathrm{~m}$ and shows its maximal abundance between salinities ranging from 2 to $16.5 \%$ (Wagner, 1964). It may constitute a significant portion of the biomass in brackish-water or hypersaline-alkaline, calcium-rich lagoons or inland lakes and the carapace remains can accumulate significantly in calcareous sediments of lagoons or lakes (Benson, 1975). Today in the Sea of Azov, Cyprideis occurs in living populations of several hundred thousand specimens per square meter (Caspers, 1957) and shows a similar population density in the Caspian Sea (Benson, 1976).

\section{Cyprideis sp.}

Fig.11e-1

Description. The carapace has a typical Cyprideis shape with a subovate contour in lateral view and a very slightly arched dorsal margin. The greatest width of the valve lays in the third-half of the length. The ventral margin is almost straight and continues smoothly onto the anteriorand the posterior end. The valves surface shows a finely pitted ornamentation. Noticeable is the small size of this species compared to the tubercles bearing and distantly larger $C$. torosa. It is however possible to be part of the C. torosa group. Dimension: Female: $1=0,75-0,83 \mathrm{~mm}, \mathrm{~h}$ $=0,41-0,44 \mathrm{~mm}, \mathrm{~b}=0,34-0,37 \mathrm{~mm}$; Male: $1=0,74-$ $0,76 \mathrm{~mm}, \mathrm{~h}=0,38-0,40 \mathrm{~mm}$.

Family Hemicytheridae Puri, 1953

Genus Tyrrhenocythere Ruggieri, 1955

Tyrrhenocythere pontica (Livental) in Agalarova et al., 1961

Fig. 12a-1

1961 Cythereis pontica Livental in litt.

\section{Trachileberis ponti-}

- Agalarova et al., 1961

(pl. LXXXII, figs. 2,

3a, b, c; pl. LXXXV,

figs. 2-4.
ca (Livental)
1977 Tyrrhenocythere pontica (Livental)
a, b, 2 a, b, 4.
1982 Tyrrhenocythere pontica (Livental)
- Krstič, pl. II, figs. 1, 2.
-Olteanu, p. 53, pl. VI,
figs. 1,2 . $1989 \begin{aligned} & \text { Tyrrhenocythere } \\ & \text { pontica (Livental) }\end{aligned}$
1995 Tyrrhenocythere - Olteanu, p. 301, pl. pontica (Livental) 25, fig. 8 . pontica (Livental) fig. c-1; pl. IIId.
2001 Tyrrhenocythere
1999 Tyrrhenocythere - Gliozzi, p. 201, pl. II, pontica (Livental)
2001 Tyrrhenocythere pontica (Livental)
2013 Tyrrhenocythere - Van Baak, p. 124, pl. pontica (Livental) $4 \mathrm{~b}, 21$.

Description. The carapace has a rectangular to oblongoval shape in lateral view and possess a distinct eye spot at the anterodorsal corner. The anterior end is broadly rounded and passes smoothly onto the ventral margin that shows a depression in the anterior third and displays to a different degree pronounced crest. The hinge margin runs almost straight, passing smoothly onto the rounded anterior border with an obtuse angle. The posterior end exhibits a shoulder and is rounded in its lower part. The outer margin of the carapace is surrounded by a fine rim that stretches from the anterior end along the entire ventral margin and stops in the middle of the posterior end. There it is extending onto the shoulder and broadens it slightly. The valves surface is covered with small to medium sized cells that have thin-walled faces. Towards the posteriorand the anterior end the ornamentation is turning into medium-sized longitudinally running meshes. A more or less pronounced crest is running parallel along the ventral margin that in generally seems to be more pointed in juvenile specimens. The marginal zone is quite broad and harbours a number of branched pore channels. The muscle scar consists of two rows of imprints, owing to the division of the two median imprints into upper and lower ones. The hinge is well developed heterodont. The marginal zone is broad and displays a number of branched pore channels. Dimension: Female: $1=0,88-0,96 \mathrm{~mm}, \mathrm{~h}$ $=0,53-0,58 \mathrm{~mm}, \mathrm{~b}=0,45-0,48 \mathrm{~mm}$; Male: $1=0,95-$ $1,12 \mathrm{~mm}, \mathrm{~h}=0,50-0,55 \mathrm{~mm}, \mathrm{~b}=0,45-0,48 \mathrm{~mm}$.

Ecology. The living representatives of the genus are generally occurring in mesohaline waters (9-13\%) but also tolerate lower salinities. They can be found at a variety of depths ranging from $0-30 \mathrm{~m}$ (Krstić, 1977 for T. amnicola (Sars)) down to $200 \mathrm{~m}$ in the Caspian Sea (Yassini and Ghahreman, 1976 for T. scitula). Krstić (1977) estimated that the fossil species of Tyrrhenocythere lived in shallow waters with a salinity ranging from 5-15\%. 


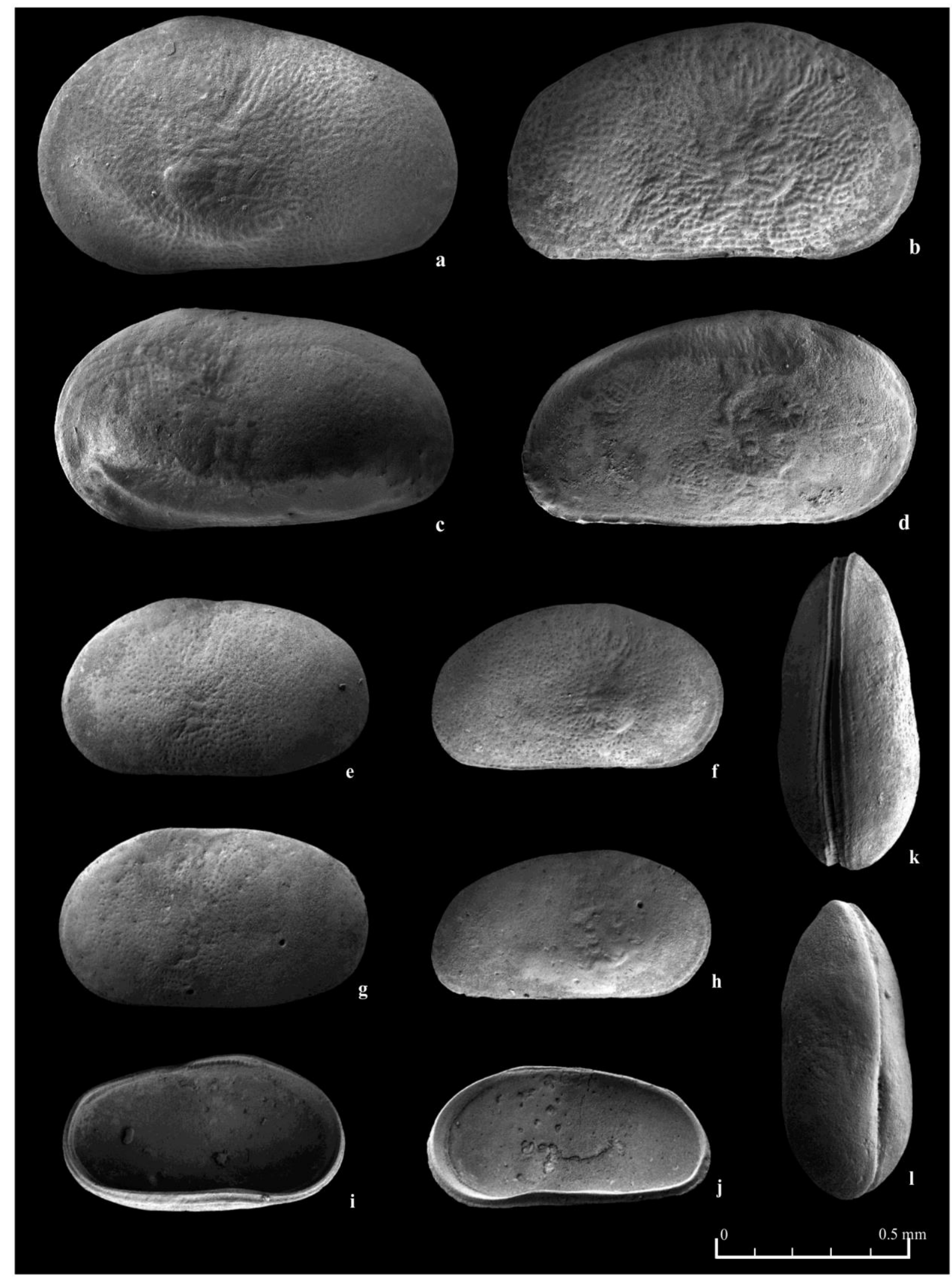

Fig. 11a-d Cyprideis torosa (Jones), un- nodded specimens; a LV, external view,, ; b RV, external view,, ; c LV, external view, ô; d RV, external view, ô; e-l Cyprideis sp.; e, g LV, external view, o+; f RV, external view,, ; h RV, external view,

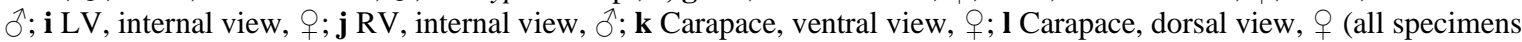
from sample DE06, Faber Quarry, Kocabaş, Denizli). 


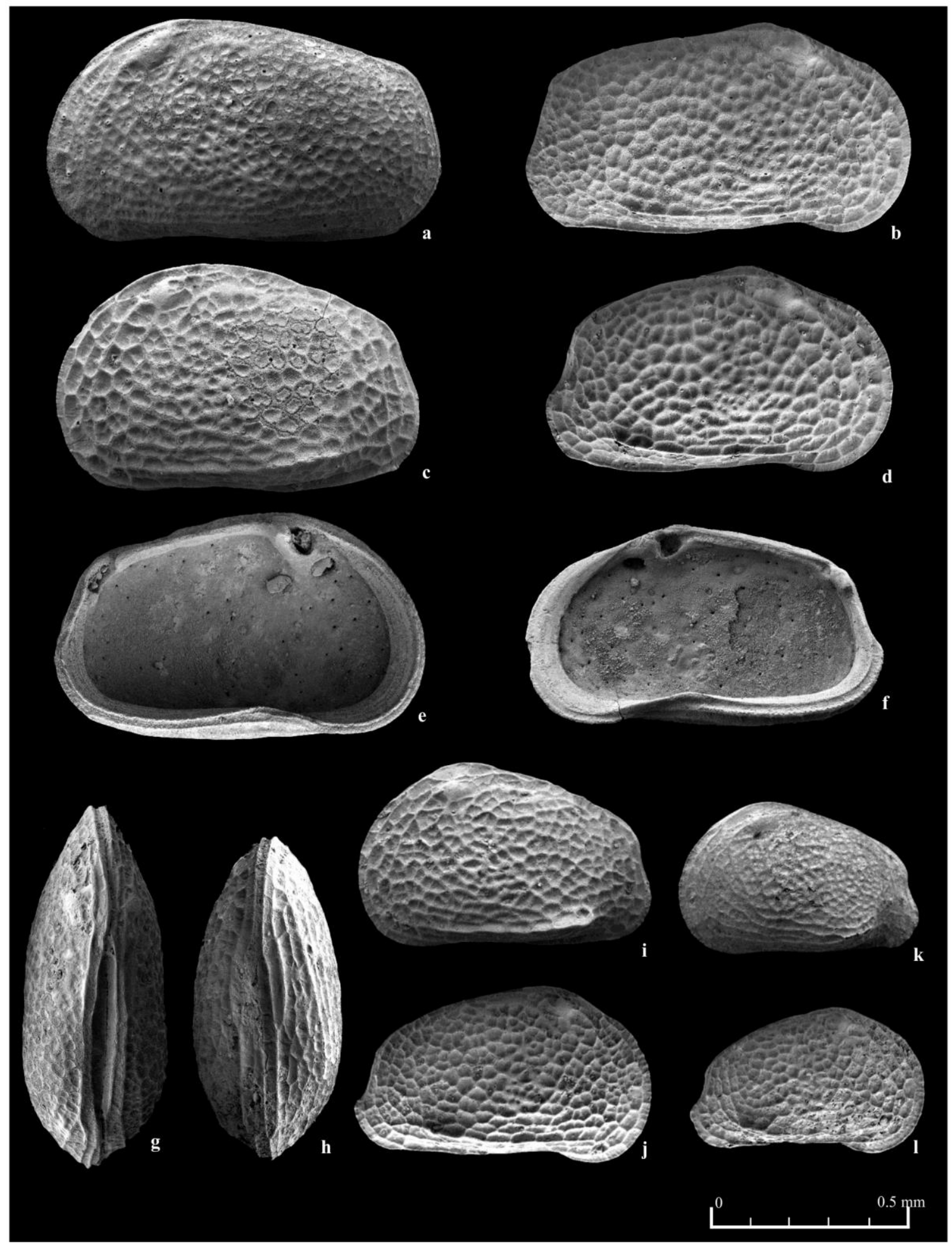

Fig. 12a-l Tyrrhenocythere pontica (Livental); a LV, external view, §ో; b RV, external view, ふૈ; c LV, external view, $\rho_{+}$d RV, external view, $\odot$; e LV, internal view, + ; f RV, internal view, $\circ$; g Carapace, dorsal view, ơ; h Carapace, ventral view, $\bigcirc$; i LV, external view, A1 juvenile; j RV, external view, A1 juvenile; k LV, external view, A2 juvenile; I RV, external view, A2 juvenile (all specimens from sample DE06, DE08 and DE11, Faber Quarry, Kocabaş, Denizli). 
Tyrrhenocythere ex. gr. bailovi (Livental) in Mandelstam et al., 1962

Fig. 13a-m

$\begin{array}{cll}1956 & \text { Cythereis bailovi } & \begin{array}{l}\text {-Suzin, p. 146, pl. VII, } \\ \text { fig. 19 }\end{array} \\ 1962 & \begin{array}{l}\text { Trachyleberis } \\ \text { bailovi (Liv.) }\end{array} & \text { - Mandelstam, p. 151, pl. } \\ \text { 20, fig. 9. }\end{array}$

Description. The carapace is rectangular to oblong in lateral view. The anterior end is broadly rounded with an arcuate slope in the lower part. The posterior end has a weakly pronounced shoulder that in general seems to be more prominent on the RV. The part below the shoulder is rounded whereas the area above it is steeply sloping. The ventral margin is concave in the anterior third, and the dorsal margin is almost straight, sloping gently towards the posterior end. The valves surface is covered by a fine pitted ornamentation. Towards the posterior-and the anterior end the ornamentation is turning into medium-sized longitudinally running meshes. The described features, excluding the ornamentation, are much more visible from the interior view. The marginal zone is broad and displays a number of branched pore channels. The muscle scar consists of two rows of imprints, owing to the division of the two median imprints into upper and lower ones. The hinge is well developed heterodont. Dimension: Male: $1=1,00-1,14 \mathrm{~mm}, \mathrm{~h}=0,55-0,62 \mathrm{~mm}$, $\mathrm{b}=0,45 \mathrm{~mm}$; Female: $1=0,85-1,07 \mathrm{~mm}, \mathrm{~h}=0,50-$ $0,61 \mathrm{~mm}$.

\section{Tyrrhenocythere sp. 1}

Fig. 14a-h

Description. The carapace of this species strongly resembles the rectangular to oblong-oval shape observed in $T$. pontica. The valve appears slightly more compressed and devoid the crest but otherwise bears most of the previously described morphological features. The posterior end bears a weakly pronounced shoulder and below continues in a rounded fashion onto the ventral margin that shows concavity in the anterior third. The part above the weakly pronounced shoulder is steeply sloping and passing onto the dorsal margin that is steeply rising until the anterior third where the valve shows its maximum width. From the highest point, the dorsal margin rapidly slopes down to the otherwise rounded anterior. Unlike the small to medium sized cell ornamentation observed on $T$. pontica, or the finely pitted surface coverage of Tyrrhenocythere ex. gr. bailovi, this species shows larger pits. Dimension: Male: $1=1,07-1,08 \mathrm{~mm}, \mathrm{~h}=0,60-0,62 \mathrm{~mm}$; Female: $1=$ $0,83-0,97 \mathrm{~mm}, \mathrm{~h}=0,59-0,60 \mathrm{~mm}$.

\section{Tyrrhenocythere sp. 2}

Fig. 14i-m
Description. The carapace is rectangular in lateral view. The anterior end is broadly rounded and passes smoothly onto the ventral margin that shows a depression in the anterior third of the valve. This feature and other characteristics, excluding the ornamentation, are far more visible from the interior view. The posterior end bears a shoulder under which it is rounded. The greatest height is in the anterior third of the valve. From that point the dorsal margin slopes and passes smoothly onto the anterior end. Towards the posterior it dips gently before steeply sloping above the mentioned shoulder. The valves surface appears smooth but also displays weakly and irregularly distributed pitted-type ornamentation. Towards the posterior-and the anterior end medium-sized longitudinally running meshes are visible. The degree of the described ornamentation varies strongly between individual specimens. The marginal zone is broad and displays a number of branched pore channels. Dimension: Male: $1=0,97-$ $0,10 \mathrm{~mm}, \mathrm{~h}=0,50-0,52 \mathrm{~mm}$; Female: $1=0,80-0,85 \mathrm{~mm}$; $\mathrm{h}=0,46-0,50 \mathrm{~mm}$.

Family Leptocytheridae Hanai, 1957

Genus Leptocythere Sars, 1925

Amnicythere multituberculata (Livental, 1929)

Fig. 15k-o

1929 Cythere multitu- - Livental, p. 14, pl. 1, berculata figs. 36-38.

1962 Cythere multitu- - Mandelstam et al., p. berculata Liv- 299, pl. 37, fig. 6.

ental

1972 Leptocythere - Sokač, p. 71, pl. 32, fig. multituberculata 14-15.

Livental

1973 Leptocythere - Kristić, p.86; text-fig. (Amnicythere?) 116; pl. III, fig. 8. multituberculata (Liv.)

1986 Leptocythere - Yassini, p. 27, pl. 10, multituberculata fig. 1-3.

1989 Leptocythere (?) - Olteanu, pl. VI. fig. 5-6. multituberculata (Livental)

1995 Amnicythere multituberculata (Livental)

2011 Leptocythere (Amnicythere) multituberculata (Livental)

2013 Amnicythere multituberculata (Livental)

- Olteanu, p. 345, pl. XVI, fig. 1-8.

- Olteanu, p. 159, pl. IX, fig. 5 .

- Van Baak et al., p. 124, fig. 4,16 .

Description. The carapace has an elongated shape and is set with a maximum of four large tubercles. The tubercles as well as the space between them are covered with a more or less pronounced but distinct wide-sized mesh pattern. The hinge margin is almost straight, passing 


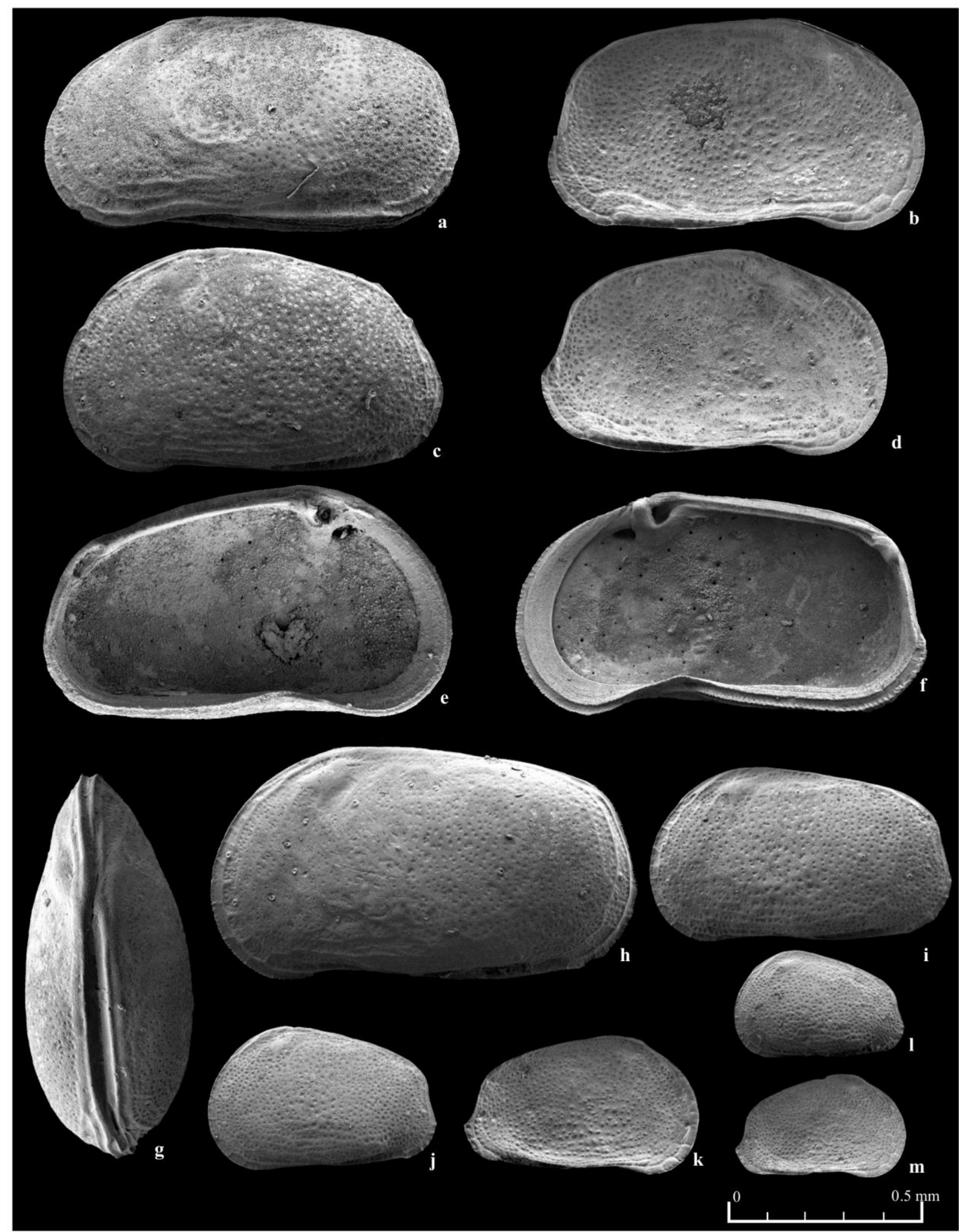

Fig. 13a-m Tyrrhenocythere ex. gr. bailovi (Livental) in Mandelstam et al., 1962; a LV, external view, ठ̂; b RV, external

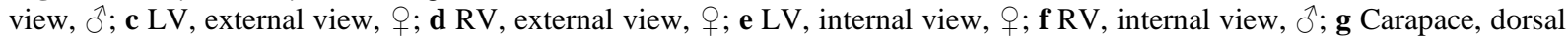
view, ; $\mathbf{h}$ LV, external view, ${ }^{7} ; \mathbf{i}$ LV, external view, A1 juvenile; $\mathbf{j}$ LV, external view, A2 juvenile; $\mathbf{k}$ RV, external view, A2 juvenile; I LV, external view, A3 juvenile; m RV, external view, A3 juvenile (all specimens from sample DE06, DE08 and DE11, Faber Quarry, Kocabaş, Denizli). 


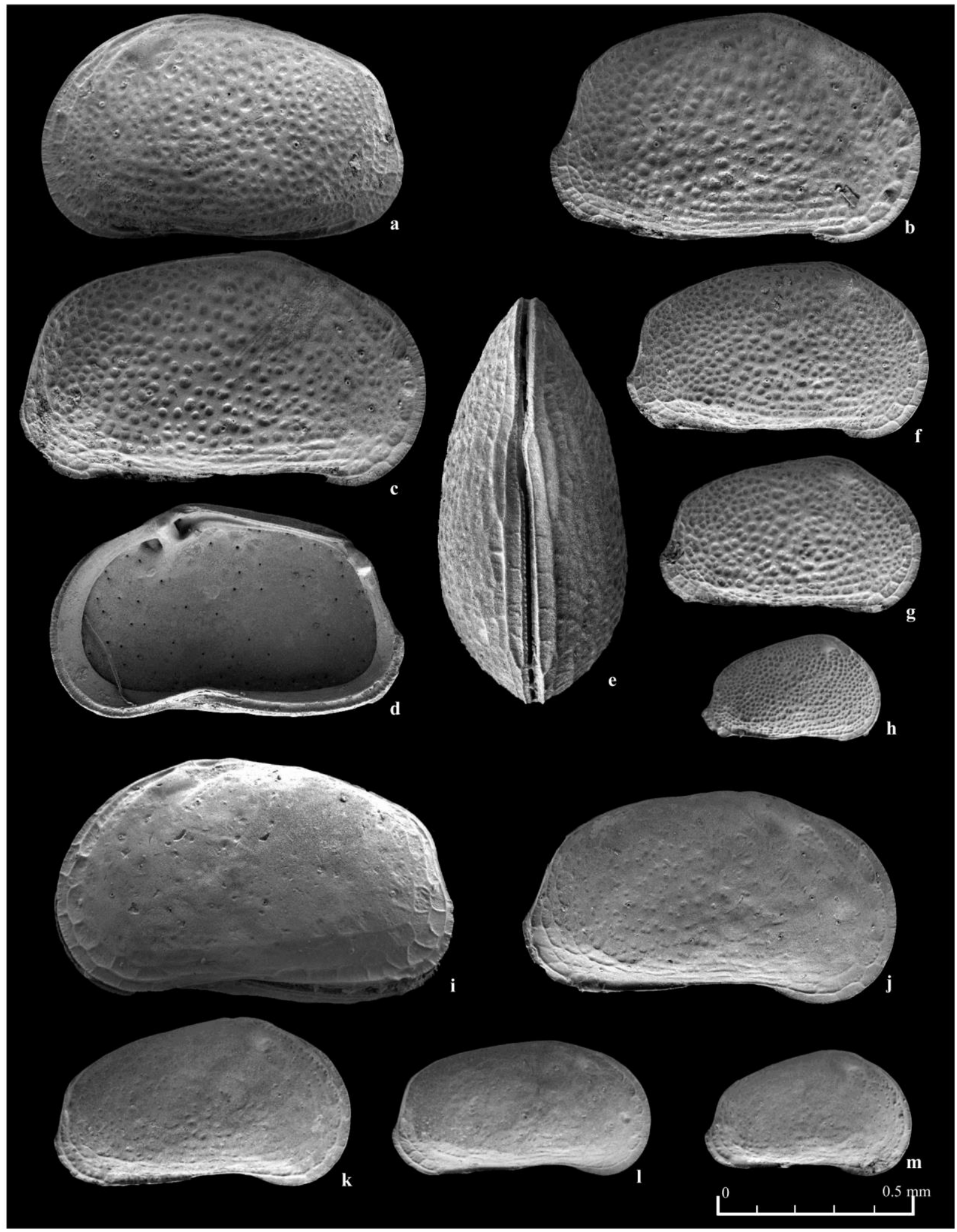

Fig. 14a-h Tyrrhenocythere sp. 1; a LV, external view,, ; b RV, external view, $\circ$; c RV, external view, $\jmath^{\lambda}$; d RV, internal view, O+; e Carapace, ventral view, $\hat{\jmath}$; f RV, external view, A1 juvenile; g RV, external view, A2 juvenile; h RV, external view, A3 juvenile. i-m Tyrrhenocythere sp. 2; i LV, external view, + ; j RV, external view, ô; $\mathbf{k}$ RV, external view, A1 juvenile; I RV, external view, A2 juvenile; m RV, external view, A3 juvenile (all specimens from sample DE14, Faber Quarry, Kocabaş, Denizli). 
smoothly onto the rounded anterior border with an obtuse angle. The transition onto the posterior border forms a ledge through the posterior "hinge ear". Both borders merge smoothly with the ventral margin, which is medially depressed. Both the anterior-and posterior margins can contain a number of irregular distributed small sized tubercles. The marginal zone is broadly developed and is hosting a number of spaced, straight running pore canals. Dimension: Male: $1=0,60-0,62 \mathrm{~mm}, \mathrm{~h}=0,3-0,32 \mathrm{~mm}$; Female: $1=0,55-0,60 \mathrm{~mm} ; \mathrm{h}=0,26-0,31 \mathrm{~mm}$.

Ecology. L. multituberculata has been mentioned by Grossi et al. (2015) as part of a "CyprideisLoxoconchidae assemblage", representing low mesohaline and shallow water conditions. Living representatives of the species were described by Gofman (1966) and Yassini (1986) from the central and southern Caspian Basins at salinities of $11.5-18.25 \%$.

Amnicythere aff. pediformis (Schornikov, 1966)

$$
\text { Fig. 15a-j }
$$

$\begin{array}{lll}1966 \mathrm{a} & \begin{array}{l}\text { Leptocythere pedi- } \\ \text { formis }\end{array} & \begin{array}{l}\text { - Schornikov, pp. 33-35, } \\ \text { text-fig. } 2 .\end{array} \\ 2005 & \text { Leptocythere sp. 2 } & \text { - Boomer et al.: pl. 1, fig. } \\ 2010 & \begin{array}{l}\text { Amnicythere pedi- } \\ \text { formis }\end{array} & \text { - Boomer et al., p. 129, } \\ \text { (Schornikov,1966) } & \text { pl. 1, fig.13. } \\ & \text { Tarasov, 1996 }\end{array}$

Description. The carapace has an elongated shape and an almost straight dorsal margin that runs parallel to the slightly sinuous ventral margin. The carapace is covered by a fine to regular punctuation that gets slightly coarser in the postero-ventral region and decreases in size towards all margins. In the central part of the valve the punctuation tends to run more or less parallel and is being separated by fine crests that tend to be more visible within the median area. Females show a coarser reticulation towards the posterior end and a slight posteroventral swelling. Close to the anterior end, that is broadly rounded, several small tubercles (pore-conuli) can occur. Dimension: $\mathrm{l}=0,58-0,63 \mathrm{~mm}, \mathrm{~h}=0,26-0,30 \mathrm{~mm}$.

Remarks. The species shares similarities with Leptocytere nata (Marcova), however the original drawing of the holotype does not allow a proper comparison. The Yassini (1986) illustrated specimen, referred to as Leptocythere nata Markova, shows a similar kind of ornamentation though it appears much finer. Leptocythere gorganensis Yassini bears a similar ornamentation as our species but appears to be more pointed posteriorly. Leptocythere casusa Markova in Agalarova et al., 1961 closely resembles our specimen, although the ornamentation net exposes more polygonal aspects. Amnicythere stepanaitysae (Sheneider) is similar, but according to the original description, possess one elongated tubercula in the posteroventral area.

Ecology. The species occurs in contemporaneous deposits within the Caspian Sea (Boomer et al., 2005) and Pleistocene to recent assemblages of the Black Sea (Boomer et al., 2010).
Family Loxoconchidae Sars, 1925

Genus Loxoconcha Sars, 1866

Genus Loxoconchissa Triebel and Malz, 1969

Subgenus Loxocaspia Schornikov, 1973

Loxoconchissa (Loxocaspia) aff. reticulata Faranda, Gliozzi and Ligios, 2007

Fig. 16a-p

$\begin{array}{lll}2007 & \text { Loxoconchissa } & \text { - Faranda, Gliozzi and } \\ \text { (Loxocaspia) } & \text { Ligios, p. 317, fig. 8 (1- } \\ \text { reticulata } \text { nov. } & \text { 10). } \\ \text { sp. } & \end{array}$

Description. The carapace has an oval rhomboidal to elliptical shape in the lateral view. The species shows remarkable sexual dimorphism. The female carapace is slightly oblique oval rhomboidal in shape, high, compressed and the ventral and dorsal margins run almost parallel, the ventral margin is being arched. The straight running dorsal margin passes smoothly onto the broadly rounded anterior end as well as onto the narrower converging posterior end. The maximum width of the carapace is slightly behind mid-length, close to where the eye-spot can be observed in the anterodorsal corner. The ornamentation is made up of irregular meshes separated by thick muri that cover the entire surface of the valve. The male carapace is slightly more elongated in shape and shows a broadly flattened anterior area and a well pronounced tubercle in the posterior part. Within the posterior area the ornamentation becomes less pronounced or in some cases is missing completely. The rest of the valves surface reticulation follows the margins and forms a mesh (longitudinal running rows that are separated by ridges). The carapace of some observed specimens seems to be covered by a thin layer of secondary calcite. Dimension: Male: $1=0,60-0,62 \mathrm{~mm}, \mathrm{~h}=0,32-0,40 \mathrm{~mm}$; Female: $1=0,53-0,57 \mathrm{~mm}, \mathrm{~h}=0,30-0,34 \mathrm{~mm}$.

Ecology. The Loxoconchidae family is well known from both brackish fossil taxa as well as living genera (Faranda et al., 2007). Loxoconchissa (Loxocaspia) aff. reticulata was first described from Late Miocene sediments from northern Italy (Faranda et al., 2007).

Loxoconchissa (Loxocaspia) aff. reticulata Faranda, Gliozzi and Ligios, var. rugosa n. subsp.

Fig. 17a-o

Description. The carapace with a rhomboidal shape in lateral view is covered in a coarse to fine reticulation pattern, that consists of a greater part of longitudinally elongated meshes that become less pronounced towards the posterior end and finer in the anterior part. The degree of the ornamentation varies and, in some specimens, occurs notably coarser, also including larger pore-conuli. The species shows remarkable sexual dimorphism. The male carapace is more elongated and the most prominent feature is the presence of a single large-size tubercle in the 


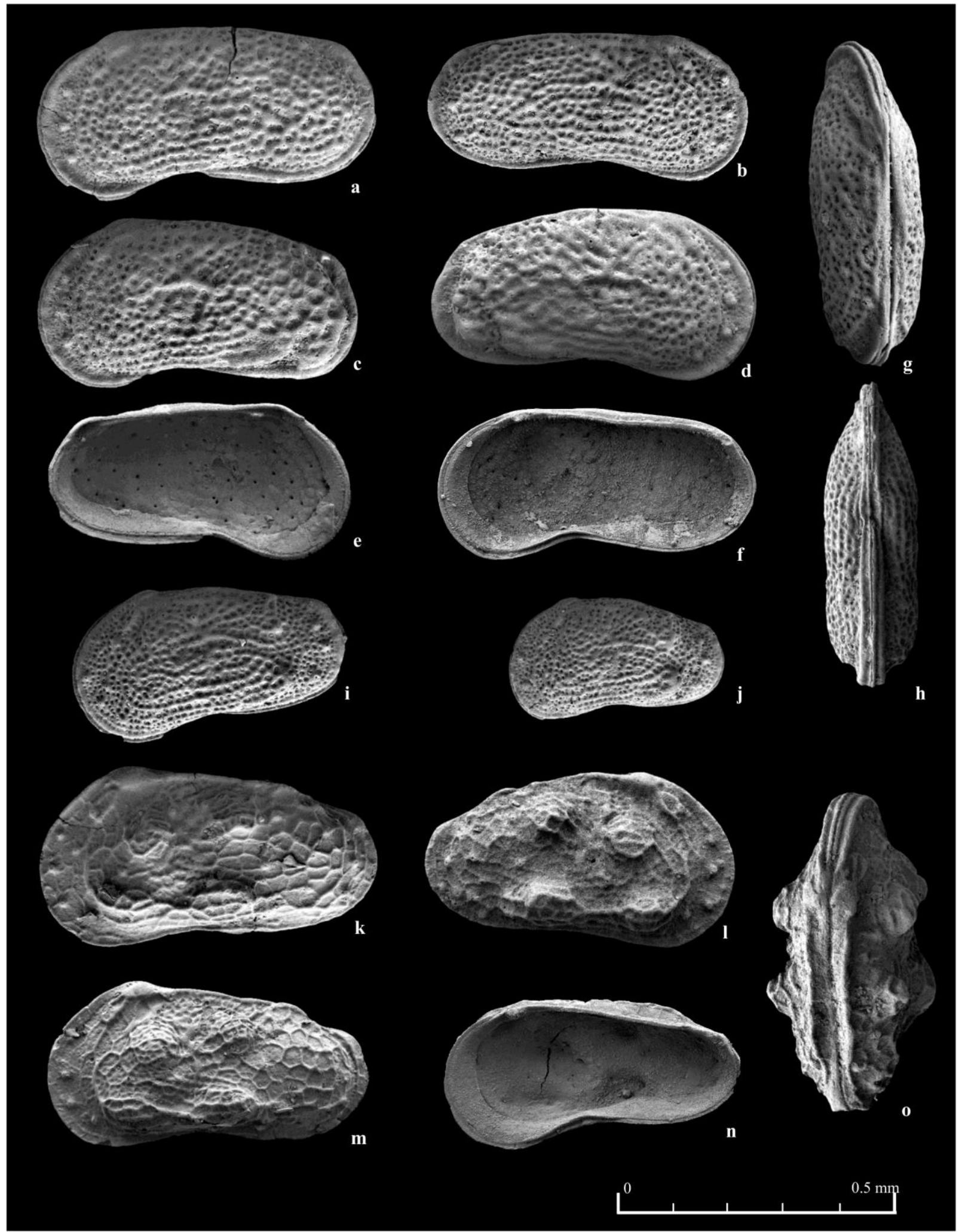

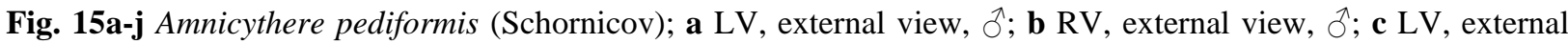
view, ?+; d RV, external view, ? $\odot$; e LV, internal view, + ; f RV, internal view, $\hat{O}^{\text {; }}$ g Carapace, dorsal view, + ; $\mathbf{h}$ Carapace, ventral view, $\widehat{\jmath}$; i LV, external view, A1 juvenile; j LV, external view, A2 juvenile; k-o Amnicythere

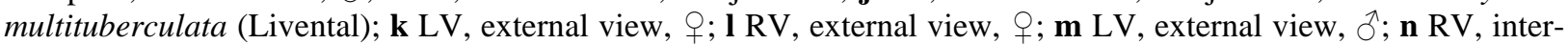
nal view, ô; o Carapace, dorsal view, ㅇ (all specimens from sample DE08, Faber Quarry, Kocabaş, Denizli). 


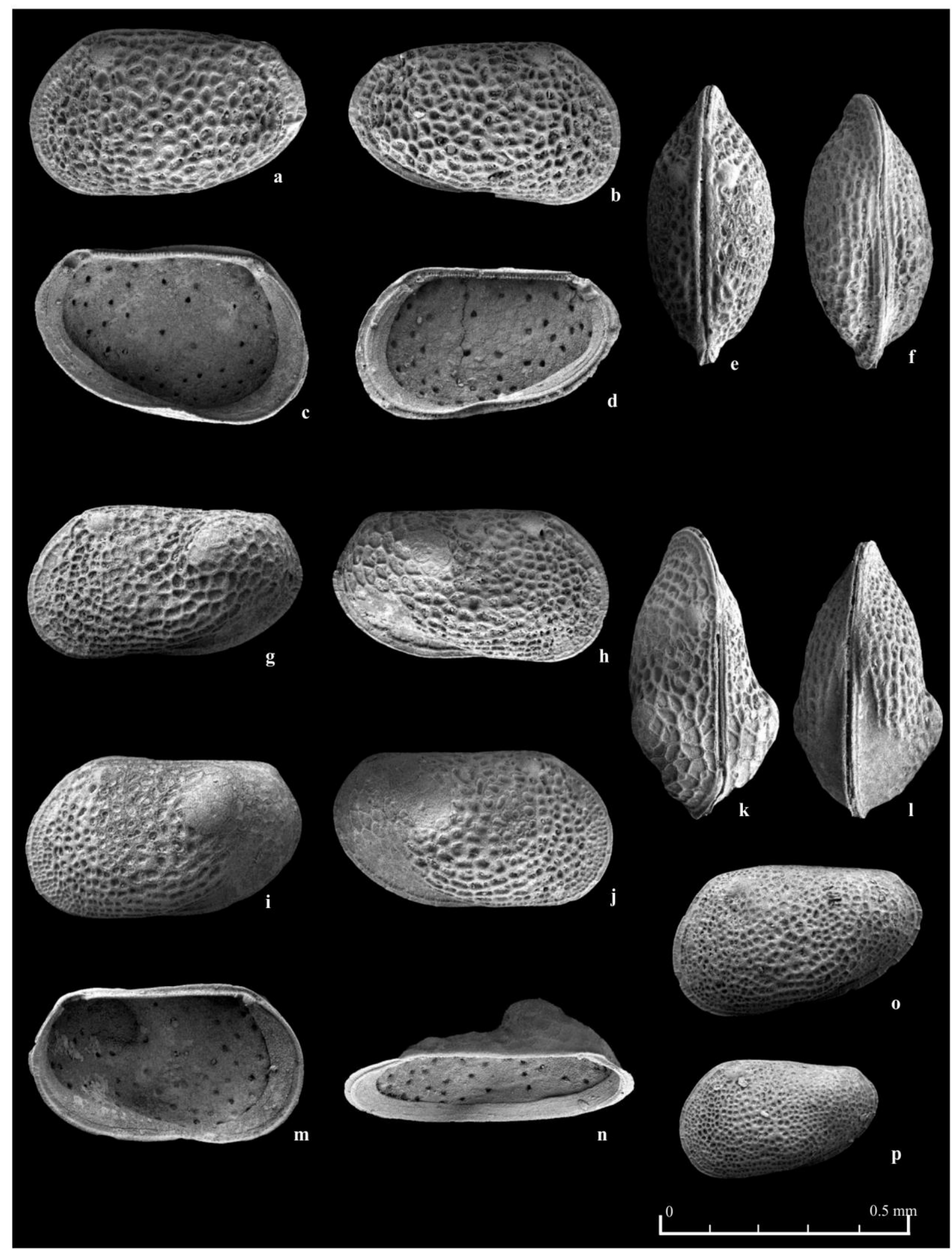

Fig. 16a-p Loxoconchissa (Loxocaspia) aff. reticulata Faranda, Gliozzi and Ligios; a LV, external view,, ; b RV, external view, + ; c RV, internal view, + ; d RV, internal view, + ; e Carapace, dorsal view, + ; f Carapace, ventral view, $\circ$; g, i LV, external view, $\partial^{\lambda} ; \mathbf{h}, \mathbf{j}$ RV, external view, $\partial^{\lambda} ; \mathbf{k}$ Carapace, dorsal view, $\partial^{\lambda} ; \mathbf{l}$ Carapace, ventral view, $\partial^{\lambda} ; \mathbf{m} L V$, internal view, $\partial^{\lambda}$; n RV, dorsal-internal view, ô; o LV, external view, A1 juvenile; p LV, external view, A2 juvenile (a-f, o, p from sample DE06, g-n from sample DE9, Faber Quarry, Kocabaş, Denizli). 


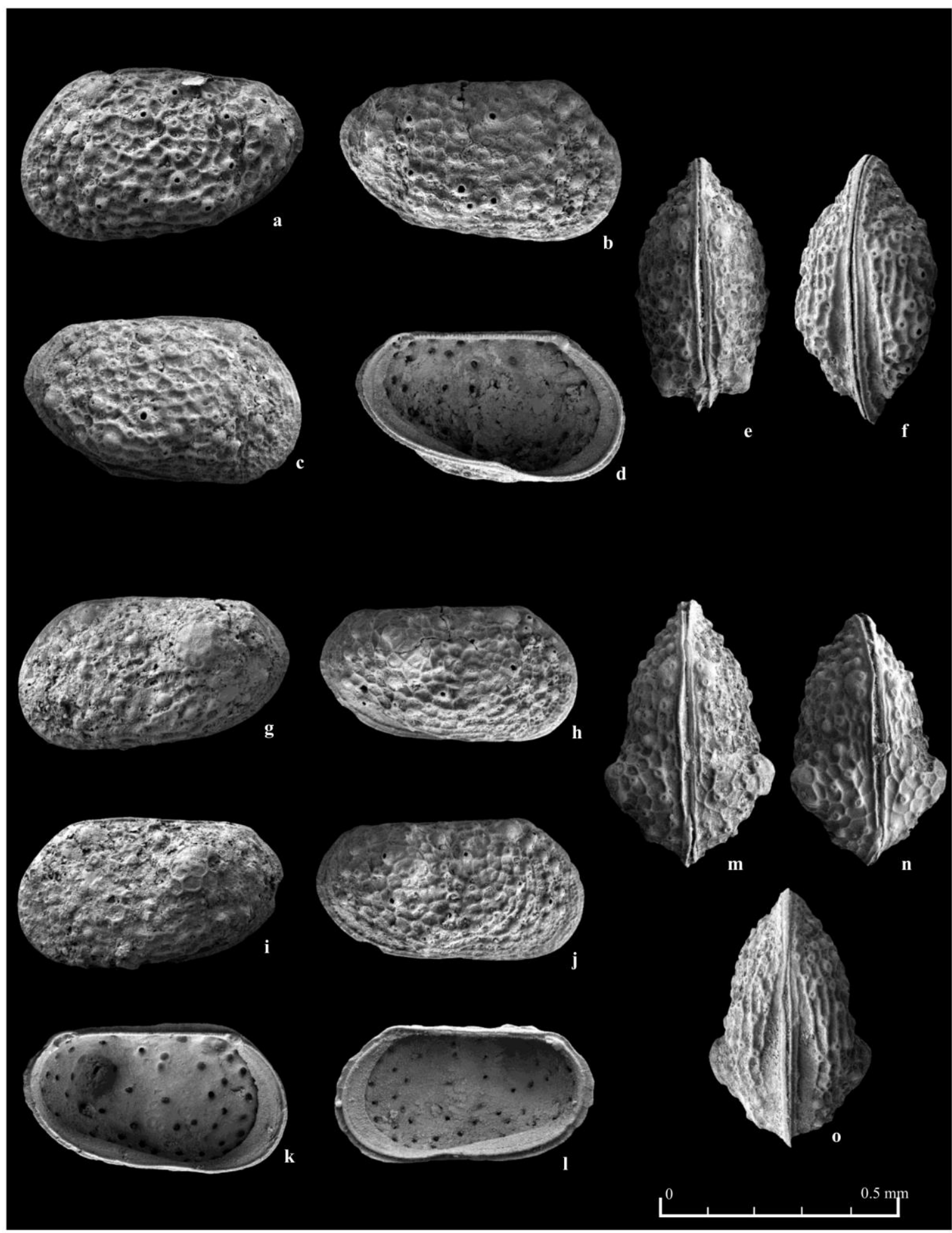

Fig. 17a-o Loxoconchissa (Loxocaspia) aff. reticulata Faranda, Gliozzi and Ligios, var rugosa, n. subsp.; a LV, external view,, ; b RV, external view,, ; c Carapace, view from RV,, ; d LV, internal view,, ; e Car-

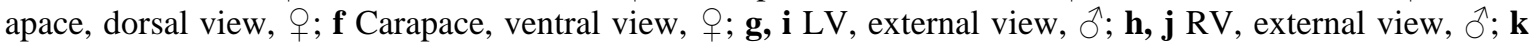

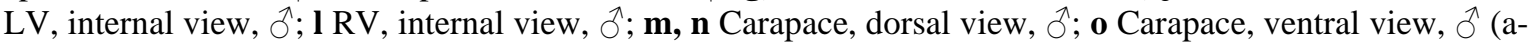
f, from sample DE09; g-o from sample DE11, Faber Quarry, Kocabaş, Denizli). 
posterior-central part of the valve that is especially impressive from the dorsal view. The tubercle appears to be more pronounced in comparison to the Loxoconchissa (Loxocaspia) aff. reticulata one and in some cases is covered by the above-mentioned reticulation pattern. A distinguishable eye-spot is present at the anterodorsal corner. The dorsal margin is straight and is smoothly and broadly rounding onto the anterior and posterior ends. The ventral margin runs parallel to the dorsal one and is slightly depressed around mid-valve. The preservation of this species in most cases is poor and a layer of secondary calcite has been observed regularly. Dimension: Male: $1=$ 0, 57- 0, $59 \mathrm{~mm}, \mathrm{~h}=0,30-0,33 \mathrm{~mm}$; Female: $1=0,52-$ $0,54 \mathrm{~mm}, \mathrm{~h}=0,30-0,32 \mathrm{~mm} \mathrm{~b}=0,16 \mathrm{~mm}$.

Ecology. The ecological preference of L. rugosa is unknown but the genus is generally known to inhabit mainly brackish and shallow marine environments (Moore, 1961; Van Morkhoven, 1962). The variability regarding the ornamentation is thought to be of genetic origin rather than environmentally driven, since the variation can be observed within a single sample. We therefore assume the presence of a strongly ornated morphotype, that can be related to the alkalinity of the lake.

\section{PALAEOECOLOGICAL IMPLICATIONS}

The detailed systematic study determined the presence of sixteen species, belonging to nine genera. Based on the taxonomic outcome we correlated species to specific environmental conditions with the goal of reconstructing the hydrological environment. An idea of the palaeoecological setting was obtained by comparing fossil ostracod communities with environmental requirements of living species. Our results indicate that the assemblage collected is dominated by a mixture of freshwater (species of Candona, Prionocypris, Cypria, Lineocypris and Darwinula) and oligohaline to mesohaline forms (species of Cyprideis, Tyrrhenocythere, Loxoconchissa and Amnicythere genera).

The assemblage includes abundant occurrences of Candona negelcta, Prionocypris zenkeri, Cyrpideis torosa, Tyrrhencythere pontica, Loxoconchissa (Loxocaspia) aff. reticulata and less common occurrences of Cypria sp., Lineocypris sp., Darwinulina stevensovi, Cyprideis sp., Tyrrhenocythere ex. gr. bailovi, T. sp. 1, T. sp. 2, Amnicythere pediformis, A. mutlituberculata and Loxoconchissa (Loxocaspia) aff. reticulata var. rugosa. n. subsp. Every sample contains all of the above mentioned taxa. Noded specimens of Cyprideis torosa are commonly observed and represent, together with Tyrrhenocythere pontica, the most common occurring species. There has been an ongoing debate over the genetically versus environmentally driven development of noded $C$. torosa. The majority of studies indicates that specimens with a smooth carapace occur at "high" salinities, while those with tubercles are found in habitats of low salinity $(<$ 6\%o) (Kilenyi, 1972; Keyser and Aladin, 2004; Keyser, 2005; Boomer et al., 2017). Nevertheless, Schornikov (1973) described noded C. torosa in the Aral Sea at much higher salinities (up to 96\%o), demanding the need to further investigate the occurrence of nodation within much higher saline environments (De Deckker and Lord, 2017).
For our studied lake environment it is worth mentioning that the water chemistry was most likely affected by the input of calcium rich waters coming from the nearby travertine springs (Rausch et al., 2019 accepted in Geobios). The effect of alkalinity on the life cycle and in particular the effect on nodosity of $C$. torosa needs to be examined more closely in the future as some of these parameters may be important factors controlling the valve calcification (De Deckker and Lord, 2017). The observed assemblage with smaller Cyprideis sp. (Fig. 11e-1), falling within the range of size variation discussed by Boomer et al. (2017), can be related to salinity oscillations. As all the Cyprideis species occur within the same sample, salinity-driven changes in size can be excluded. How the concentrations of certain elements in this high alkaline environment influence the life cycle is beyond the aim of the current study. The need of supplementary data to clarify the possible impact of alkalinity on the influence of variability of primary reticulation is required for other groups as well.

The negative impact of the palaeohydrological conditions inside the lake, are further supported by the restricted faunal diversity. The observed assemblage is not monospecific but devoid the diverse faunal range of typical marine-or freshwater environments. High abundances and low diversities assemblages are linked to drastic turnovers caused by regional or global events, well reported globally throughout the Mesozoic and Cenozoic interval (Colin and Lethiers, 1988). How high alkaline water bodies influence species diversity is fairly unknown, but the observed fossil population is suggesting a limited impact. Restricting environments, especially in semi-enclosed and marginal marine basins are known to create endemic communities, as observed in the Paratethys region. The Black and Caspian Sea are the present-day remnants of the Paratethys, a large epicontinental sea developing as a northern branch of the Tethys, starting in the early Oligocene (Rögl, 1999; Popov et al., 2006; Krijgsman et al., 2019). The region has a very dynamic history of basin development, being dominated by periodic isolation and (re)connecting events leading to the evolution of a highly diverse and endemic ostracod fauna. Some of the observed genera (Tyrrhenocythere, Amnicythere and Loxoconcha) originated from the Paratethys and can still be found today in the Black and Caspian Sea, and may indicate that the herein described Pleistocene fauna might be the relict of a Paratethyan influenced long-lived lake environment that prevailed inside the Denizli Basin since the late Neogene (Wesselingh et al., 2008). Supplementary data is required to clarify the relationship to the longlived lake that existed during the Pliocene-early Pleistocene near the town of Tosunlar (Alçiçek et al., 2015). As the modern graben system in the western Anatolian extensional province is still relatively young, possibly around middle Miocene in age (Ten Veen et al., 2009), it is likely that the lake has continued to exist until the Pleistocene also in the studied area. Our results further support the faunal relations well known within Neogene basins of Anatolia to the Paratethys, indicating that the region once might have functioned as a satellite basin of the Paratethys. 


\section{CONCLUSION}

The detailed study of the ostracod assemblages, collected from the fluvio-lacustrine deposits of the Faber quarry, provides new insights about the palaeoecological conditions inside the Denizli Basin. The fauna reflects an anomalohaline, lake environment of early Pleistocene age with the water chemistry broadly affected by the proximity of thermal calcite rich springs that induced the deposition of travertine. The encountered assemblage is not indicative for assigning an age but the succession was previously dated based on cosmogenic nuclides $\left({ }^{26} \mathrm{Al} /{ }^{10} \mathrm{Be}\right)$, palaeomagnetic measurements and large mammal-based biostratigraphy, suggesting that the deposition occurred between $\sim 1.6$ and $1.1 \mathrm{Ma}$ (Lebatard et al., 2014; Boulbes et al., 2014).

The ostracod assemblage is lacking a higher diversity, typical for freshwater or marine water environments. Low diversity assemblages are characteristic for transitional habitats, supporting our assumption of a restricted water body. The diversity remains equal along the entire succession and a total of sixteen species have been recorded, shedding light on the palaeoecological conditions. The co-occurrence of anomalohaline (oligohaline to mesohaline) water taxa and mainly freshwater cypridoid ostracods suggest a shallow water lake environment with a salinity no greater than lower mesohaline $(\sim 18 \%)$. The input of calcium-rich water from nearby travertine springs is assumed to have had a major impact on the faunal diversity development.

\section{ACKNOWLEDGEMENTS}

This study would not have been possible without the help and access throughout the entire year provided by the management of the Faber Quarry. In particular, we thank Haydar Alptekin, Koray Ateş and Uğur Korkmaz and the director Nejdet Karakuyu for their support. We thank Hülya and Cihat Alçiçek for their valuable contribution on the geology of the Denizli Basin. We further thank the Faculty of Geology and Geophysics, Department of Geology at Bucharest University (Romania) for giving access to the laboratories and the Microcosmos Laboratory from the Geological Institute of Romania for providing the scanning electron microscope (SEM) necessary for taking the high-resolution images. We are grateful to Andrei Briceag (GeoEcoMar Bucharest) and Viorel Ionesi (University of Iaşi) for improving the manuscript. This research is part of the PRIDE project (Pontocaspian RIse and DEmise), which is funded by the European Union's Horizon 2020 research and innovation program, under the Marie Sklodowska-Curie (grant agreement № 642973).

\section{REFERENCES}

Agalarova, D.A., Kadyrova, Z.K. and Kulieva, S.A., 1961. Ostracoda from Pliocene and Post-pliocene deposits of Azerbaijan. Baku, 1-420.

Alçiçek, H., Varol, B., Özkul, M., 2007. Sedimentary facies, depositional environments and palaeogeographic evolution of the Neogene Denizli Basin of SW Anatolia, Turkey. Sedimentary Geology 202, 596-637.
Alçiçek, M.C., Mayda, S., Titov, V.V., 2013. Lower Pleistocene stratigraphy of the Burdur Basin of SW Anatolia. Comptes Rendus Palevol. 12, 1-11.

Alçiçek H. Wesselingh F. Alçiçek M.C., 2015. Paleoenvironmental evolution of the late Pliocene-early Pleistocene fluvio-deltaic sequence of the Denizli Basin (SW Turkey). Palaeogeography, Palaeoclimatology, Palaeoecology 437, 98-116.

Alçiçek, H., Bülbül, A. and Alçiçek, M.C., 2016. Hydrogeochemistry of the thermal waters from the Yenice geothermal field (Denizli Basin, Southwestern Anatolia, Turkey). Journal of Volcanology and Geothermal Research 309, 118-138.

Alçiçek H. Bülbül A. Capezzuoli E. Brogi A. Liotta D. Meccheri M. Riggueri G. Yavuzer İ. Alçiçek M.C., 2018. Origin, evolution and geothermometry of thermal waters in the Gölemezli Geothermal Field, Denizli Basin (SW Turkey). Journal of Volcanology and Geothermal Research 3, 83-100.

Altunel, E., 1994. Active tectonics and the evolution of Quaternary travertines at Pamukkale, Western Turkey. PhD thesis, University of Bristol, pp. 236.

Benson, R.H., 1975. The origin of the psychrosphere as recorded in changes of deepsea ostracode assemblages. Lethaia 8(1), 69-83.

Benson, R.H., 1976. Changes in the ostracodes of the Mediterranean with the Messinian salinity crisis. Palaeogeography, Palaeoclimatology, Palaeoecology 20: 147-170.

Boomer I., Whatley, R. and Aladin, N.V., 1996. Aral Sea Ostracoda as environmental indicators. Lethaia, 29(1), 77-85.

Boomer, I., von Grafenstein, U., Guichard, F., and Bieda, S., 2005. Modern and Holocene sublittoral ostracod assemblages (Crustacea) from the Caspian Sea: a unique brackish, deep-water environment. Palaeogeography, Palaeoclimatology, Palaeoecology, 225(1-4), 173-186.

Boomer, I.A.N., Guichard, F. and Lericolais, G., 2010. Late Pleistocene to Recent ostracod assemblages from the western Black Sea. Journal of Micropalaeontology, 29(2), 119-133.

Boomer, I., Frenzel, P. and Feike, M., 2017. Salinitydriven size variability in Cyprideis torosa (Ostracoda, Crustacea). Journal of Micropalaeontology 36 (1), 6369.

Boulbes N. Mayda S. Titov V.V. Alçiçek M.C. 2014. Les grands mammifères pléistocènes des travertins du Bassin de Denizli, Sud-ouest de l'Anatolie, Turquie (The large Upper Villafranchian mammals from the Denizli Basin travertines, southwest Anatolia, Turkey). Anthropologie 118, 44-73.

Bozkurt, E., 2003. Origin of NE-trending basins in western Turkey. Geodinamica acta 16(2-6), 61-81.

Brady, G.S. and Robertson, D., 1870. The Ostracoda and Foraminifera of Tidal Rivers. With an analysis and descriptions of the Foraminifera, by Henry B. Brady, FLS. Annals and Magazine of Natural History, 6(31), 1-33.

Briceag, A., Stoica, M., Oaie, G. and MelinteDobrinescu, M.C., 2012. Late Holocene microfaunal and nannofloral assemblages of the NW Black Sea. GeoEcoMarina, 18, 65-73. 
Caspers, H., 1957. Black Sea and Sea of Azov. Geological Society of America, 67, 1: 801-890.

Chyzer, C., 1858. Ueber die Crustaceen--Fauna Ungarns. Verhandlungen der kaiserlich-königlichen zoologischbotanischen Gesellschaft in Wien, 8: 505-515.

Colin, J.-P., and Lethiers, F., 1988. The importance of ostracods in biostratigraphic analysis. Ostracoda in the earth sciences. Elsevier, Amsterdam, 175-199.

De Deckker, P. and Lord, A., 2017. Cyprideis torosa: a model organism for the Ostracoda? Journal of Micropalaeontology 36(1), 3-6.

Diebel, K. and Pietrzeniuk, E., 1969. Ostracoden aus dem Mittelpleistozän von Süßenborn bei Weimar. Paläontologische Abhandlungen, 3, 463-488.

Diebel, K. and Wolfschläger, H., 1975. Ostrakoden aus dem jungpleistozänen Travertine von Ehringsdorf bei Weimar. Abhandlungen des Zentralen Geologischen Instituts Berlin, Paläontologische Abhandlungen, 23: 91-136.

Diebel, K. and Pietrzeniuk, E., 1984. Jungpleistozaene Ostrakoden aus Sedimenten der Parkhoehlen von Weimar. Quartärpaläontologie, 5, 285-319.

Faranda, C., Gliozzi, E., and Ligios, S., 2007. Late Miocene brackish Loxoconchidae (Crustacea, Ostracoda) from Italy. Geobios, 40(3), 303-324.

Freels, D., 1980. Limnische Ostrakoden aus Jungtertiar und Quartar der Turkei. Geologisches Jahrbuch, 39, 3-169.

Frenzel P., Matzke-Karasz R., Viehberg F.A., 2006. Muschelkrebse als Zeugen der Vergangenheit. Biologie in unserer Zeit, vol. 36, no. 2: 102-108.

Fuhrmann, R., 2008. Die Ostrakoden-und Molluskenfauna des Auelehmprofils Zeitz (Landkreis Burgenland) und ihre Aussage zum Klima sowie zur Landnutzung im jüngeren Holozän Mitteldeutschlands. Mauritiana, 20(2), 253-281.

Fuhrmann, R., 2012. Atlas quartärer und rezenter Ostrakoden Mitteldeutschlands (pp. 1-320). Altenburg: Naturkundliches Museum Mauritianum.

Gliozzi, E., 1999. A late Messinian brackish water ostracod fauna of Paratethyan aspect from Le Vicenne Basin (Abruzzi, central Apennines, Italy). Palaeogeography, Palaeoclimatology, Palaeoecology, 151(1-3), 191-208.

Gofman, E.A.E., 1966. Ekologija sovremennych i novokaspijskich ostrakod Kaspijskogo morja. Izd. Hauka, p. 141.

Grossi, F., Gliozzi, E., Anadón, P., Castorina, F. and Voltaggio, M., 2015. Is Cyprideis agrigentina Decima a good paleosalinometer for the Messinian Salinity Crisis? Morphometrical and geochemical analyses from the Eraclea Minoa section (Sicily). Palaeogeography, Palaeoclimatology, Palaeoecology, 419, 75-89.

Hartmann, G., 1966. Dr. H.G. Broon's Klassen und Ordnungen des Tierreichs, 5. Arthropoda, 1. Crustacea, 2(4/1): 1-216.

Higuti, J., Lansac-Tôha, F.A., Velho, L.F.M., Pinto, R.L., Vieira, L.C.G. and Martens, K., 2009. Composition and distribution of Darwinulidae (Crustacea, Ostracoda) in the alluvial valley of the upper Paraná River, Brazil. Brazilian Journal of Biology, 69(2), 253-262.
Horne, D.J., Cohen, A. and Martens, K., 2002. Taxonomy, morphology and biology of Quaternary and living Ostracoda. The Ostracoda: applications in Quaternary research, 131, 5-36.

Jones, T.R., 1850. Description of the Entomostraca of the Pleistocene Beds of Newbury Copford, Clacton and Grays. The Annals and magazine of natural history. 6(2): 25-28.

Kappelman, J., Alçiçek, M.C., Kazanc1, N., Schultz, M., Özkul, M., Şen, Ş., 2008. First Homo erectus from Turkey and implications for migrations into temperate Eurasia. American Journal of Physical Anthropology 135, 110-116.

Kaymakçı,, N., 2006. Kinematic development and paleostress analysis of the Denizli Basin (Western Turkey): implications of spatial variation of relative paleostress magnitudes and orientations. Journal of Asian Earth Sciences, 27(2), 207-222.

Keyser, D., 1977. Ecology and zoogeography of recent brackish-water Ostracoda (Crustacea) from southwest Florida. Aspects of ecology and zoogeography of recent and fossil Ostracoda, 207-222.

Keyser, D., 2005. Histological peculiarities of the noding process in Cyprideis torosa (Jones)(Crustacea, Ostracoda). Hydrobiologia, 538(1-3), 95-106.

Keyser, D. and Aladin, N., 2004. Noding in Cyprideis torosa and its causes. Studia Quaternaria, 21, 19-24.

Kilenyi, T.I., 1972. Transient and balanced genetic polymorphism as an explanation of variable noding in the ostracode Cyprideis torosa. Micropaleontology, 4763.

Kingston, J.D., 2007. Shifting adaptive landscapes: progress and challenges in reconstructing early hominid environments. American Journal of Physical Anthropology: The Official Publication of the American Association of Physical Anthropologists, 134(45), 20-58.

Koçyiğit, A., 2005. The Denizli graben-horst system and the eastern limit of the western Anatolian continental extension: basin fill, structure, deformational mode, throw amount and episodic evolutionary history, SW Turkey. Geodinamica Acta 18, 167-208.

Krijgsman, W., Tesakov, A., Yanina, T., Lazarev, S., Danukalova, G., Van Baak, G.C.G., Agustí, J., Alçiçek, M.C., Aliyeva, E., Bista, D., Bruch, A., Büyükmeriç, Y., Bukhsianidze, M., Flecker, R., Frolov, P., Hoyle, T.M., Jorissen, E.L., Kirscher, U., Koriche, S.A., Oms, O., Rausch, L., Singarayer, J., Stoica, M., Van de Velde, S.V., Titov, V.V., Wesselingh, F.P., 2019. Quaternary time scales for the Pontocaspian domain: interbasinal connectivity and faunal evolution. Earth Science Reviews 188, 1-40.

Krstić, N., 1973. Biostratigraphy of the congerian beds in the Belgrade region on the basis of Ostracoda with the description of the species of the genus Amplocypris. Institute for Geological and Mining Explorations and Investigation of Nuclear and Other Minerals Raw Materials, Monographs, 4, 208.

Krstić, N., 1977. The ostracod genus Tyrrhenocythere. In Aspects of ecology and zoogeography of Recent and fossil Ostracoda (pp. 395-405). Dr. W. Junk bv Publishers The Hague. 
Lebatard, A.-E., Alçiçek, M.C., Rochette, P., Khatib, S., Vialet, A., Boulbes, N., Bourlès, D.L., Demory, F., Guipert, G., Mayda, S., Titov, V.V., Vidal, L., de Lumley H., 2014. Dating the Homo erectus bearing travertine from Kocabaş (Denizli, Turkey) at least 1.1 Ma. Earth and Planetary Science Letters 390, 8-18.

Lips, A.L.W., Cassard, D., Sözbilir, H., Y1lmaz, H., 2001. Multistage exhumation of the Menderes Massif, western Anatolia (Turkey). International Journal of Earth Sciences, 89, 781-792.

Lister, G.S., 1988. Stable isotopes from lacustrine Ostracoda as tracers for continental palaeoenvironments. Ostracoda in the Earth Sciences. Elsevier, Amsterdam, 20, 210-218.

Livental, V.E., 1929. Ostracoda of Akchagilian and Apsheronian beds of the Babazan Section. Izvestiya Azerbajdzahnskogo Politekhnischeskogo Instituta, 1, $1-58$.

Mandelstam, M.I., Markova, L., Rosyeva, T. and Stepanaitys, N., 1962. Ostracoda of the Pliocene and postPliocene deposits of Turkmenistan. Turkmenistan Geological Institute, Ashkhabad (1) 288.

Mandelstam, M.I. and Schneider, G.F., 1963. Les ostracodes fossiles de l'USSR, famille Cyprididae. Trudy VNIGRI, 203, 1-242.

Martens, K., Rossetti, G. and Fuhrmann, R., 1997. Pleistocene and recent species of the family Darwinulidae Brady \& Norman, 1889 (Crustacea, Ostracoda) in Europe. Hydrobiologia, 357(1-3), 99-116.

Matzke-Karasz, R. and Witt, W., 2005. Ostracods of the Paratethyan Neogene Kılıç and Yalakdere Formations near Yalova (İzmit Province, Turkey). Zitteliana, 115133.

Meisch, C., 2000. Crustacea: Ostracoda. Süßwasserfauna von Mitteleuropa. In: Schwoerbel J. \& Zwick P. (Hrsg.): Süßwasserfauna von Mitteleuropa. - 8(3): 1522, Spektrum Akademischer Verlag, Heidelberg/Berlin.

Moore, R.C., 1961. Glossary of morphological terms applied to Ostracoda. Arthropoda, 3, 47-56.

Müller, O.F., 1776. Zoologiae Danicae prodromus, seu animalium Daniae et Norvegiae indigenarum characteres, nomina, et synonymy imprimis popularium. Hallageriis, Havniae.: i-xxxii; 1-282.

Olteanu, R., 1982. Genus Tyrrhenocythere Ruggieri, in the Dacic Basin. Dari de Seama ale Sedintelor Institutul de Geologie si Geofizica, 3. Paleontologie, 69, 47-58.

Olteanu, R., 1989. New ostracodes in upper Neogene from Romania. Memoriile Institutului de Geologie si Geofizica, 34, 123-182.

Olteanu, R., $1995 . \quad$ Dacian ostracodes. Chronostratigraphie und Neostratotypen, Neogene der Zentrale Paratethys, 9, 268-386.

Oltenau, R., 2001. Hemicytherinae Subfamily (Ostracoda, Crustacea) and its Species in Paratethys BrackishWater Facieses (Neogene, Carpathian Areas). Their Morphology and Taxonomy. Studii si cercetari de Geologie, 46, 71-110.

Oltenau, R., 2011. Atlas of the Pannonian and Pontian ostracods from the eastern area of the Pannonian Basin. GeoEcoMarina, 17, 135-179.
Pipík, R. and Bodergat, A.M., 2005. Espèces du groupe de Candona candida, Candona neglecta et quelques Candona à l'aspect morphologique problématique (Candonidae, Ostracoda) du Bassin de Turiec (Miocène supérieur, Slovaquie). In Annales de paléontologie (Vol. 91, No. 4, pp. 279-309). Elsevier Masson.

Popov, S.V., Shcherba, I.G., Ilyina, L.B., Nevesskaya, L.A., Paramonova, N.P., Khondkarian, S.O., Magyar, I., 2006. Late Miocene to Pliocene palaeogeography of the Paratethys and its relation to the Mediterranean. Palaeogeography, Palaeoclimatology, Palaeoecology 238(1-4), 91-106.

Rausch, L., Alçiçek, H., Vialet, A., Boulbes, N., Mayda, S., Titov, V.V., Stoica, M., Charbonnier, S., Abels, H.A., Tesakov, A.S., Moigne, A.M., Andrieu-Ponel, V., De Franceschi, D., Neubauer, T.A., Wesselingh, F.P., Alçiçek, M.C., 2019. An integrated reconstruction of the early Pleistocene palaeoenvironment of Homo erectus in the Denizli Basin (SW Turkey), accepted in Gebios.

Rögl, F., 1999. Short note Mediterranean and Paratethys. Facts and hypotheses of an Oligocene to Miocene paleogeography (Short overview). Geologica Carpathica 50(4), 339-349.

Sars, G.O., 1887. Nye bidrag til kundskaben om middelhavets invertebratfauna: 4. Ostracoda Mediterranea (Sydeuropaeiske Ostracoder). Archiv for Mathematik og Naturvidenskab, 12, 173-324.

Sars, G.O., 1925. An account of the Crustacea of Norway. Cytheridae, 177, pls-81.

Schornikov, E.I., 1973. Ostracoda of the Aral Sea. Zoologicheskii Zhurnal, 52, 1304-1314.

Schornikov, E.I., 1966. Leptocythere (Crustacea, Ostracoda) of the basin of the Sea of Azov and ofthe Black Sea. Zoological Journal, 45(1), 32-49 (in Russian).

Şimşek, Ş., 1984. Denizli-Kızıldere-TekkehamamTosunlar-Buldan-Yenice alanının jeolojisi ve jeotermal enerji olanakları. Mineral Res. Expl. Direct. Turkey (MTA), Scientific Report, (7846), 85.

Sokač, A., 1972. Pannonian and Pontian Ostracode fauna of Mt. Medvednica: Panonska i pontska fauna ostrakoda Medvednice (Vol. 11). - Palaeontologia Jugoslavica, 11: 1-140, Zagreb.

Sözbilir H. 2005. Oligo-Miocene extension in the Lycian orogen: evidence from the Lycian mollase basin, SW Turkey. Geodinamica Acta 18, 255-282.

Stoica, M., Lazăr, I., Krijgsman, W., Vasiliev, I., Jipa, D., \& Floroiu, A., 2013. Paleoenvironmental evolution of the East Carpathian foredeep during the late Miocene-early Pliocene (Dacian Basin; Romania). Global and Planetary Change, 103, 135-148.

Sun, S., 1990. Denizli-Uşak Arasının Jeolojisi ve Linyit Olanakları. Mineral Res. Expl. Direct. Turkey (MTA), Scientific Report No: 9985, Ankara, Turkey (in Turkish) pp. 92.

Suzin, A.V., 1956. Ostracoda from Tertiary deposits of the North Caucasus. Gostoptekhizdat, Moscow, 191.

Ten Veen, J.T., Boulton, S.J. and Alçiçek, M.C., 2009. From palaeotectonics to neotectonics in the Neotethys realm: The importance of kinematic decoupling and inherited structural grain in SW Anatolia (Turkey). Tectonophysics, 473(1-2), 261-281. 
Tunoğlu, C., 2001. New Pontian Tyrrhenocythere (Ostracoda) species from Arakli (Trabzon), Eastern Black Sea Region of Turkey. Yerbilimleri 23, 129-143.

Tunoğlu, C., Ternel, A., Gençonglu, H. and Riha, J., 1995. Pliocene Ostracoda association and environmental characteristics of Sivrihisar (Eskisehir) area, Central Anatolia, Turkey. Ostracoda \& Biostratigraphy. Balkema, Rotterdam, 265-275.

Van Baak, C.G., Vasiliev, I., Stoica, M., Kuiper, K.F., Forte, A.M., Aliyeva, E. and Krijgsman, W., 2013. A magnetostratigraphic time frame for Plio-Pleistocene transgressions in the South Caspian Basin, Azerbaijan. Global and Planetary Change, 103, 119-134.

Van Baak, C.G., Mandic, O., Lazar, I., Stoica, M. and Krijgsman, W., 2015. The Slanicul de Buzau section, a unit stratotype for the Romanian stage of the Dacian Basin (Plio-Pleistocene, Eastern Paratethys). Palaeogeography, palaeoclimatology, palaeoecology, 440, 594-613.

Van Morkhoven, F. P., 1962. Post-palaeozoic ostracoda: their morphology, taxonomy, and economic use. 1. General. Elsevier Vol. 2, 1-204.

Vekua, M.L., 1975. The ostracods of the Kimmerian and Kujalinikian deposits of Abkhazia and their stratigraphic significance. Metzniereba, Tibilisi.

Vialet, A., Guipert, G., Alçiçek, M.C. 2012. Homo erectus found still further west: Reconstruction of the Kocabaş cranium (Denizli, Turkey). Comptes Rendus Palevol 11, 89-95.

Vialet, A., Guipert, G., Alçiçek, M.C., de Lumley, M.-A. 2014. La calotte crânienne d'Homo erectus archaïque de Kocabaş, Bassin de Denizli, Anatolie, Turquie (The archaic Homo erectus skullcap from Kocabaş, Denizli Basin, Anatolia, Turkey). Anthropologie 118, 74-107.
Vialet, A., Prat, S., Wils, P., Alçiçek, M.C., 2018. The Kocabaş hominin (Denizli Basin, Turkey) at the crossroad of Eurasia: New insight from morphometrical and cladistical analyses. Comptes Rendus Palevol 17, 17-32.

Wagner, C.W., 1964. Ostracods as environmental indicators in Recent and Holocene estuarine deposits of The Netherlands. Pubblicazioni della Stazione zoologica di Napoli, 33(suppl.), 480-495.

Westaway, R., 1993. Neogene evolution of the Denizli region of western Turkey; Journal of Structural Geology 15, 37-53.

Wesselingh, F.P., Alçiçek, H., Magyar, I., 2008. A Late Miocene Paratethyan mollusc fauna from the Denizli Basin (southwestern Anatolia, Turkey) and its regional palaeobiogeographic implications. Geobios 41, 861-879.

Whatley, R.C., 1983a. The application of Ostracoda to Paleoenvironmental Analysis. Applications of Ostracoda, University of Houston Geoscience, p. 51 -77.

Whatley, R.C., 1983b. Some simple procedures for enhancing the use of Ostracoda in paleoenvironmental analysis. Norwegian Petroleum Directorate Bulletin, 2: 219-145.

Yassini, I., 1986. Ecology, paleoecology and stratigraphy of ostracodes from Upper Pliocene and Quaternary deposits of the South Caspian Sea, North Iran. Lake Illawarra Management Committee, 1-78.

Yassini, I. and Ghahreman, A., 1976. Récapitulation de la distribution des ostracodes et des foraminifères du lagon de Pahlavi, province de Gilan, Iran du nord. Revue de Micropaléontologie, 19(3), 172-190. 